OPEN ACCESS

Edited by:

Franziska Hess,

RWTH Aachen University, Germany

Reviewed by:

Farrukh Khalid,

Hamad bin Khalifa University, Qatar

Beibei Liu,

Nanjing University, China

*Correspondence:

Peter Styring

p.styring@sheffield.ac.uk

Specialty section:

This article was submitted to

Hydrogen Storage and Production,

a section of the journal

Frontiers in Energy Research

Received: 07 July 2020

Accepted: 20 January 2021

Published: 29 March 2021

Citation:

Ghavam S, Vahdati M, Wilson IAG and Styring P (2021) Sustainable Ammonia

Production Processes.

Front. Energy Res. 9:580808.

doi: 10.3389/fenrg.2021.580808

\section{Sustainable Ammonia Production Processes}

\author{
Seyedehhoma Ghavam ${ }^{1}$, Maria Vahdati ${ }^{2}$, I. A. Grant Wilson ${ }^{3}$ and Peter Styring ${ }^{1 *}$ \\ ${ }^{1}$ Department of Chemical and Biological Engineering, The University of Sheffield, Sheffield, Uinted Kingdom, ${ }^{2}$ School of \\ Construction Management and Engineering, University of Reading, Reading, Uinted Kingdom, ${ }^{3}$ School of Chemical Engineering, \\ University of Birmingham, Birmingham, Uinted Kingdom
}

Due to the important role of ammonia as a fertilizer in the agricultural industry and its promising prospects as an energy carrier, many studies have recently attempted to find the most environmentally benign, energy efficient, and economically viable production process for ammonia synthesis. The most commonly utilized ammonia production method is the Haber-Bosch process. The downside to this technology is the high greenhouse gas emissions, surpassing $2.16 \mathrm{kgCO}_{2}-\mathrm{eq} / \mathrm{kg} \mathrm{NH}_{3}$ and high amounts of energy usage of over $30 \mathrm{GJ} /$ tonne $\mathrm{NH} 3$ mainly due to the strict operational conditions at high temperature and pressure. The most widely adopted technology for sustainable hydrogen production used for ammonia synthesis is water electrolysis coupled with renewable technologies such as wind and solar. In general, a water electrolyzer requires a continuous supply of pretreated water with high purity levels for its operation. Moreover, for production of 1 tonne of hydrogen, 9 tonnes of water is required. Based on this data, for the production of the same amount of ammonia through water electrolysis, 233.6 million tonnes/yr of water is required. In this paper, a critical review of different sustainable hydrogen production processes and emerging technologies for sustainable ammonia synthesis along with a comparative life cycle assessment of various ammonia production methods has been carried out. We find that through the review of each of the studied technologies, either large amounts of GHG emissions are produced or high volumes of pretreated water is required or a combination of both these factors occur.

Keywords: ammonia production, fertilizer, energy carrier, sustainable hydrogen production, Haber-Bosch, water intensity, GHG emissions

\section{INTRODUCTION}

According to the United Nations (UN), the world's population will increase to more than 9 billion in the next 35 years $(\mathrm{FAO}, 2009)$. This population growth puts a burden on the earth's natural resources, such as the depletion of water supplies. This growth will at the same time result in higher waste production. According to the US Environmental Protection Agency (EPA), in the United States, $30 \%$ of the methane $\left(\mathrm{CH}_{4}\right)$ produced comes from livestock manure which contributes as much methane emission as the oil and gas industry. Uncontrolled decomposition of waste in landfills, if left untreated, leads to the discharge of methane which is a Greenhouse Gas (GHG) emissions and is approximately 30 times more potent than carbon dioxide $\left(\mathrm{CO}_{2}\right)$ for trapping heat throughout the first 10 years from when it is discharged. Methane accounts for $20 \%$ of the global warming that is currently being experienced (IPCC, 2013; MIT News, 2017). The Food and Agriculture Organization (FAO) of the UN also states that global food production will need to 
TABLE 1 | Energy content of various fuels in liquid state (Giddey et al., 2013).

\begin{tabular}{|c|c|c|c|c|}
\hline \multirow[t]{2}{*}{ Chemicals } & \multicolumn{2}{|c|}{ Energy content (High Heating Value (HHV)) } & \multicolumn{2}{|c|}{ Energy content (Low Heating Value (LHV)) } \\
\hline & $(\mathrm{J} / \mathbf{k g}) \times 10^{6}$ & $(\mathrm{~J} / \mathrm{L}) \times 10^{6}$ & $(\mathrm{~J} / \mathrm{kg}) \times 10^{6}$ & $(\mathrm{~J} / \mathrm{L}) \times 10^{6}$ \\
\hline Liquid hydrogen $\left(\mathrm{H}_{2}\right)$ & 141.9 & 10.1 & 119.9 & 8.5 \\
\hline Liquid ammonia $\left(\mathrm{NH}_{3}\right)$ & 22.5 & 15.3 & 18.6 & 12.7 \\
\hline Methane $\left(\mathrm{CH}_{4}\right)$ & 56.2 & 23.6 & 50.0 & 20.9 \\
\hline Methanol $\left(\mathrm{CH}_{3} \mathrm{OH}\right)$ & 22.9 & 18.2 & 20.1 & 15.8 \\
\hline Ethanol $\left(\mathrm{C}_{2} \mathrm{H}_{5} \mathrm{OH}\right)$ & 29.9 & 23.6 & 26.9 & 21.2 \\
\hline
\end{tabular}

increase by $70 \%$ to keep up with the increasing demand due to population growth (UN, 2015). About $40-60 \%$ of global food production is tied to the usage of commercial fertilizers (Roberts, 2009). Fossil fuels are the main feedstock for the fertilizer manufacturing processes.

According to the statistics, ammonia $\left(\mathrm{NH}_{3}\right)$ had a worldwide production of 235 million tonnes in 2019, making it the second highest produced chemical commodity after sulfuric acid $\left(\mathrm{H}_{2} \mathrm{SO}_{4}\right)$ (Soloveichik, 2017a). Ammonia has an important role in the agricultural industry for production of fertilizers. Other industrial applications of ammonia include its use as an energy carrier for energy storage and transportation, it can also be utilized in the production of polyimides, nitric acid, nylon, pharmaceuticals, explosive materials, refrigerants, dyes, cleaning solutions, and other industrial chemicals. (CICE, 2016).

Ammonia consists of $17.6 \mathrm{wt} \%$ hydrogen, showing that ammonia is an indirect hydrogen storage compound (Michael et al., 2015). Ammonia's energy density is $4.32 \mathrm{kWh} /$ liter, which is similar to methanol $\left(\mathrm{CH}_{3} \mathrm{OH}\right)$, and approximately double that of liquid hydrogen (Soloveichik, 2017b). Philiber (2018) points out that liquefying hydrogen is more difficult when compared to ammonia, since ammonia liquefies at $-33.4^{\circ} \mathrm{C}$ and at atmospheric pressure: Hydrogen has to be liquefied by chilling to temperatures lower than $-253^{\circ} \mathrm{C}$. One of the main challenges of utilizing hydrogen as an energy carrier is the difficulty of transporting and storing it without dissipating, and therefore being unavailable for its intended end use. Another challenge related to this dissipation is its safety during transportation and storage. Yet another challenge associated with hydrogen, used as an energy carrier, is its low energy density and difficulty in handling (Nordvang, 2017). This is due to the volumetric hydrogen energy density in liquid anhydrous ammonia (10.1 MJ/L) which is approximately 1.5 times higher than of liquid hydrogen as shown in Table 1. From a safety point of view, ammonia gas is almost the same as air, so in case of leakage ammonia rapidly dissipates into the atmosphere. However, unlike hydrogen, ammonia is not typically explosive. It is a hazardous chemical and it must be handled with care, due to its causticity and toxicity (Brown, 2016). Due to the above-mentioned factors, ammonia is seen as a practical energy vector for hydrogen. In a world with greater and greater amounts of deployed lower-carbon renewable generation able to provide the primary electricity for hydrogen electrolysis, this ammonia could be described as green ammonia.

According to Soloveitchik (2017a), ammonia is not only considered a fertilizer but also an energy carrier. In addition, with the global transition from fossil fuels to variable renewable energy sources, such as solar and wind, there is an increasing requirement for energy storage solutions that can cover various timeframes for storing the energy. Of particular interest is the capability to store energy economically for long periods of time without a significant reduction in energy, to transport the stored energy over long distances (also without significant reduction in energy), and to be able to store the energy at terawatt-hours (TWh) scales economically, perhaps only needing to charge and discharge a small number of times over a year (Wilson and Styring, 2017). These are the general characteristics of fossil fuels and help to explain why these fuels are so ubiquitous. It seems evident that fuels (gaseous, liquid or solid) are particularly useful to satisfy these characteristics and will therefore still be necessary in future energy systems due to the continued need to provide interseasonal storage (Wilson and Styring, 2017) and traded energy across global supply chains. In future low-carbon energy systems, these should therefore be regarded as lowcarbon fuels, and ammonia as a synthetic fuel that is able to meet these requirements.

\section{Widely Adopted Ammonia Production Technologies}

The technologies for ammonia production currently in use require either a steady supply of distilled water in high volumes to operate or result in high carbon dioxide production. The most commonly utilized ammonia production method is the Haber-Bosch process which has the disadvantages of high GHG emissions and high amounts of energy usage, mainly due to its high operating pressure and temperature. For sustainable ammonia production, the most widely adopted technology is water electrolysis coupled with renewable technologies such as wind and solar energy to produce the hydrogen. In general, a water electrolyzer requires a continuous stream of pretreated water with high purity levels for its operation. Moreover, for production of 1 tonne of hydrogen, 9 tonnes of water is required. In 2016, the amount of ammonia produced was reported to be 146 million tonnes globally (Cong et al., 2019). Based on this data, for the production of the same amount of ammonia through water electrolysis, 233.6 million tonnes ( 233.6 billion liters) of water is required.

Ammonia is produced in large plants ( 1,000 to $1,500 \mathrm{t} /$ day) by means of Haber-Bosch process (Soloveichik, 2017a). Globally, more than $90 \%$ of ammonia is produced from fossil fuels through this method (Hughes et al., 2015; Guerra et al., 2020). The Haber- 
Bosch process is generally powered by fossil fuels which function at temperatures in the range of $400-500^{\circ} \mathrm{C}$ and pressure in the range of 150-300 bar, usually in the presence of an iron (Fe) based catalyst (Garagounis et al., 2014; Wang et al., 2018). About 96\% of the hydrogen $\left(\mathrm{H}_{2}\right)$ required for the production of ammonia via Haber-Bosch process is derived from fossil fuels (Parkinson et al., 2018). The remaining $4 \%$ is generated from electricity which will include some indirect use of fossil fuels from coal or natural gas electrical generation (Michael et al., 2015). A typical Steam Methane Reforming (SMR) process produces approximately 9-10 tonnes of carbon dioxide equivalent $\left(\mathrm{CO}_{2 \mathrm{eq}}\right)$ for each tonne of hydrogen produced (Parkinson et al., 2018). Globally, $72 \%$ of the hydrogen manufactured for ammonia production is from the SMR process and $26 \%$ is derived from coal (IEA, 2012; Kevin Breen, 2012). In 2016, coal-based ammonia made up more than $82 \%$ of China's ammonia production (Heffer and Prud'homme, 2016).

The Haber-Bosch process has the drawback of high GHG emissions, surpassing 2.16 tonne $\mathrm{CO}_{2}$ /tonne $\mathrm{NH}_{3}$ and high amounts of energy usage of over $30 \mathrm{GJ} /$ tonne $\mathrm{NH}_{3}$ mainly due to its high pressure and temperature (Yoo, et al., 2013). Approximately $3-5 \%$ of the natural gas produced globally is utilized for ammonia production via the Haber-Bosch process (Wang et al., 2018). This figure represents nearly 1-2\% of the global energy supply (Hughes et al., 2015; Wang et al., 2018). Generally, high levels of energy are needed in the manufacture of fertilizers. Approximately $1.2 \%$ of the world's energy is used for fertilizer production, of which, $93 \%$ is nitrogen-based (IFA, 2009).

This research seeks to answer the question of, what technologies are able to address the main problems associated with the production of hydrogen required for ammonia synthesis currently in use, such as the need for a steady supply of deionized water in high volumes and/or high carbon dioxide production. In order to answer the research question, a systematic literature review was carried out. The findings within the relevant literature were then categorized and methodized by following a content analysis. Thus, this paper presents a comprehensive review of the literature on ammonia production technologies and various hydrogen production processes required for ammonia synthesis.

There is a research gap in available literature on sustainable hydrogen production processes such as $\mathrm{CH}_{4}$ assisted Solid Oxide Fuel Electrolysis Cell (SOFEC), Natural Gas Assisted Steam Electrolysis (NGASE), and dark fermentation coupled with other biological technologies consolidated in a study for ammonia synthesis. The increase in the availability of waste, lead us to focus on the use of dark fermentation integrated with other biological technologies that can use waste as their feedstock or a process that can use biogas as its input stream such $\mathrm{CH}_{4}$ assisted-SOFEC/NGASE. Bioconversion of waste through the aforementioned biological technologies into important chemical compounds such as ammonia can be a new resource recovery alternate pathway for fossil-based chemicals. These technologies will be described and reviewed in $\mathrm{CH}_{4}$ AssistedSolid Oxide Fuel Assisted Electrolysis Cell and Biological Hydrogen Production Processes in terms of efficiency, economics, and in comparison, with other processes. In Hydrogen Production Using
Solar Power and Photoelectrochemical sustainable hydrogen production using solar is reviewed and the problems associated with its scale up are discussed. In A Review of Sustainable Technologies for Ammonia Production emerging technologies for ammonia production comprised of electrochemical, Non-thermal plasma, West Virginia University (WVU), and Nitrogenase motivated peptidefunctionalized catalyst for electrochemical ammonia synthesis are critically reviewed. These technologies which are at the research and development stage have not been scaled up commercially to compete with or replace the Haber-Bosch process.

\section{Relationship Between Ammonia and Natural Gas Prices}

Access to affordable and abundant sources of ammonia production is critically important for a steady, economically viable supply to the global agriculture sector. The impact of volatility in natural gas prices significantly affects the final ammonia production price. For the manufacturing of ammonia, $70-90 \%$ of the costs are related to natural gas prices (Dincer and Bicer, 2018). Therefore, the market price of ammonia fluctuates in step with natural gas prices. The price of both natural gas and ammonia have increased in most years, the former from approximately $0.141 \$ / \mathrm{m}^{3}$ in 1975 to $0.53 \$ / \mathrm{m}^{3}$ in 2015 , and the latter from $290 \$$ /ton of $\mathrm{NH}_{3}$ in 1975 to approximately 850 \$/ton of $\mathrm{NH}_{3}$ in 2015 and reached its maximum in 2015. Between 2012 - 2016, the price of natural gas decreased globally due to the increase in natural gas production mainly in the United States (Schnitkey, 2016).

\section{Ammonia Production Using Offshore Wind}

Morgan et al. (2017) also determined that ammonia production using hydrogen powered by offshore wind is technically feasible with current technologies and its economic feasibility is based on the price of natural gas when using conventional methods. This process is comprised of: Seawater desalination, hydrogen gas production, nitrogen separation, ammonia synthesis, and ammonia storage. This study shows that ammonia plants utilizing current technologies that run on electricity exclusively, require major assistance from the grid as a backup to operate. The result of the sensitivity analysis conducted by Morgan (2013) showed that the final cost of ammonia is dependent in large part to the cost of offshore wind electricity generation.

\section{METHODS}

The aim of this study is to review the literature on conventional and new methods for sustainable ammonia production. Based on a thorough review of literature, a number of major apparent deficiencies in sustainable ammonia production technologies are described in Introduction and elaborated in Addressing Problems Associated With Current Renewable Technologies for Ammonia Production. More sustainable, lower-carbon pathways for 
ammonia production described in this study are critical to ensure food security and energy storage in a manner that is compatible with deep decarbonization efforts. In this work, a systematic review was performed based on a formulated research question: "How to produce ammonia in a sustainable manner?" The research topics were classified in three main categories: 1) Finding the most sustainable pathways for hydrogen production required for ammonia synthesis 2) Finding sustainable new emerging ammonia production technologies 3) The challenges associated with sustainable hydrogen/ ammonia production. The production of green ammonia considered in this work focuses on the use of hydrogen obtained from renewable sources. Different technologies for hydrogen production required for ammonia synthesis are evaluated in A Review of Hydrogen Production Technologies for Ammonia Synthesis. As hydrogen is the key component for ammonia synthesis, our focus needs to be on sustainable hydrogen production pathways. We assessed the two most commonly utilized technologies for ammonia production which are SMR and water electrolysis coupled with HaberBosch in terms of GHG emissions, electricity, and water consumption. The other technologies for sustainable hydrogen production, reviewed in this study are produced electrochemically $\left(\mathrm{CH}_{4}\right.$ assisted-SOFEC/NGASE $)$ and biologically (dark fermentation coupled with other technologies such as photo fermentation and anaerobic digestion). The rationale behind choosing these specific processes is that there is a research gap in available literature in consolidating the evaluation of these technologies for sustainable hydrogen production required for ammonia synthesis. The cost of production for hydrogen through the use of $\mathrm{CH}_{4}$ assisted-SOFEC is comparable to SMR in addition to being produced in a sustainable manner. The feedstock for this technology can be biogas resulting from the bioconversion of waste. According to the statistics mentioned in the introduction, reported by the EPA, the overabundance of waste streams poses a great threat to GHG control. Therefore, bioconversion of waste through dark fermentation, photo fermentation, etc. into important chemical compounds such as ammonia can be a new resource recovery alternative for fossil-based chemicals. Various emerging sustainable ammonia production technologies are presented in A Review of Sustainable Technologies for Ammonia Production and finally, a critical review of different ammonia production technologies using Life Cycle Assessment (LCA) method is described in Environmental Impact of Various Ammonia Production Processes. Based on the aim of this work, the keywords identified and the number of associated articles found were: "green "AND” hydrogen production" (23,825 articles), "green ammonia production" (83,059 articles), "energy carrier" $(15,887$ articles), "sustainable ammonia production" $(37,539$ articles), and "ammonia production" AND "Life cycle assessment" (241 articles). The analysis of articles was carried out based on the quality of research and relevancy to the review topic. In determining the papers to assess for this review we elected to focus exclusively on green and/or sustainable production technologies for hydrogen required for ammonia synthesis and ammonia production technologies. Specifically concentrating on technical and environmental assessment and excluding the economic aspects of these technologies, to avoid a tendency to value economic factors over the technical and environmental. Moreover, location assessment for determining the site suitability for ammonia production was not included in this review. Although this study's focus is to critically review sustainable hydrogen and ammonia production processes, fossil-based technologies (e.g., conventional production routes using fossil fuels) are also included in the paper for the comparison of the data/results. However, the research strategy was to search for relevant scientific papers published in scientific journals using one of the most recognized academic databases. The databases selected for the purposes of the review were Science Direct, Web of Science, Springer, Wiley, etc. The research was performed considering the period of publication from 1992- May 2020. Following the search of various databases, the results were then filtered and reviewed through three steps: On the basis of the title, keywords, abstract, and after reading the full paper. We have excluded articles that were not related to our research questions or which were duplicates. In addition, the snowball technique was used to find further relevant papers through checking the references of the collected papers and assessing these as mentioned above. As a result, a total number of 118 relevant publications were identified, of which, 116 papers are in English and two in the Italian language. Regarding the publication type, 43 research items were published as a journal article and the rest were published as dissertations, conference proceedings, government documents, reports, and handbooks. Data was collected from all the relevant papers cited in the references.

\section{A REVIEW OF HYDROGEN PRODUCTION TECHNOLOGIES FOR AMMONIA SYNTHESIS}

Ammonia is the result of the exothermic reaction between hydrogen and nitrogen shown by the equilibrium in Eq. 1.

$$
\frac{1}{2} \mathrm{~N} 2(g)+\frac{3}{2} H 2 \leftrightarrow \mathrm{NH}_{3}(g) \quad \triangle H=-93(\mathrm{~kJ} / \mathrm{mol})
$$

The main challenge for ammonia production is finding an economically viable, energy efficient, and more sustainable pathway for the production of hydrogen. Furthermore, a process in which the equilibrium is pushed further to the right is highly desirable. An overview of various production routes for the hydrogen required for ammonia synthesis is depicted in Figure 1.

A comparison of various hydrogen production processes (thermochemical, biochemical, and electrochemical) along with a brief description of their feedstock and their source of energy is shown in Table 2.

Various technologies for hydrogen production with their energy inputs and state of commercialization are described in 


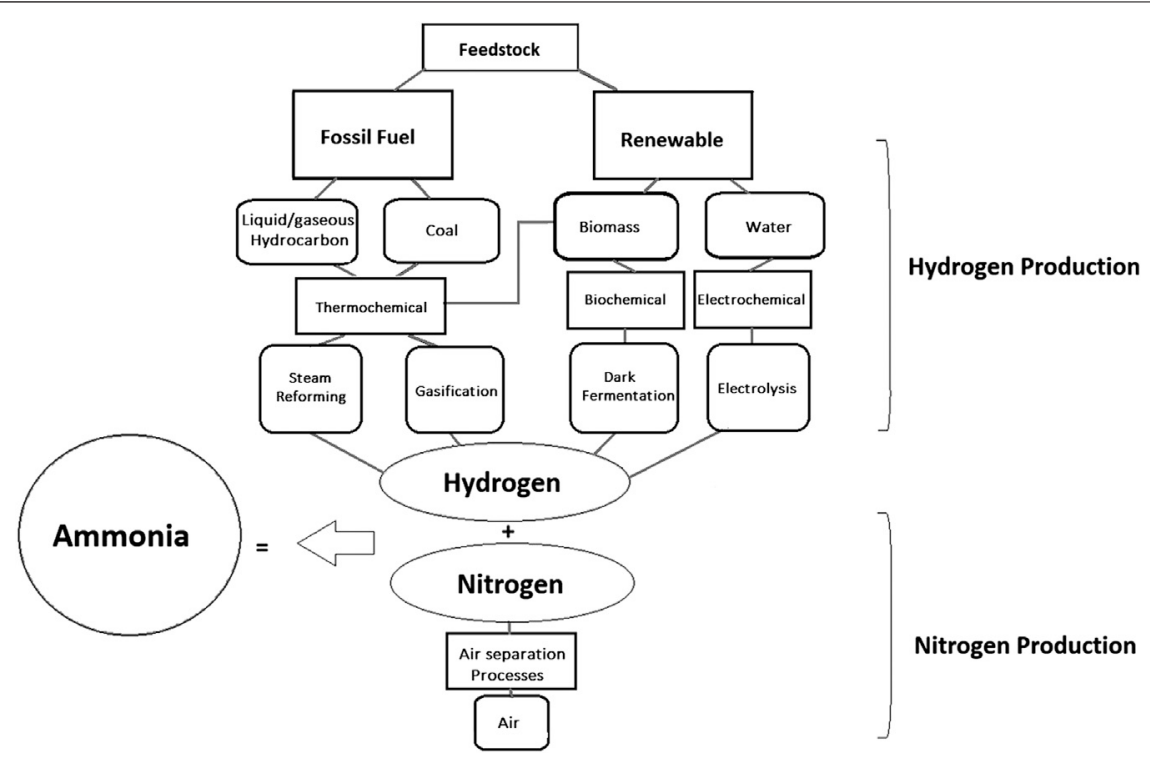

FIGURE 1 | Various hydrogen production routes.

Table 2. These technologies produce hydrogen directly without the need to be upgraded into pure hydrogen.

\section{$\mathrm{CH}_{4}$ Assisted-Solid Oxide Fuel Electrolysis Cell}

SOFEC technology is a type of electrolysis which aims to produce hydrogen at lower costs compared to other available electrolysis technologies. In the SOFEC, methane is added to the anode side of the electrolyzer, the decomposition potential (voltage) of water is decreased, and this results in lower energy usage and a higher conversion ratio of electricity for hydrogen production. The system efficiency is up to $70 \%$ with respect to primary energy. Wijers (2011) also mentions a laboratory test based on SOFEC which showed an $85 \%$ decrease in the demand of electrical energy in comparison to the best alternative electrolysis available. Pham et al., (2000) was the first study to propose adding fuel (methane) to the anode, thus lowering the voltage needed for the electrolysis process. The final cost of hydrogen through $\mathrm{CH}_{4}$ assisted-SOFEC is competitive compared to hydrogen prices via SMR method (Luo et al., 2014). However, its high operational temperatures and long-term instability limit its practical application. Figure 2 shows a schematic of $\mathrm{CH}_{4}$ assisted-SOFEC with the chemical reactions involved (Figure 2).

\section{Natural Gas Assisted Steam Electrolyzer}

Martinez-Frias et al., (2003), created a lab-scale model known as NGASE in which the operating voltage of this electrolyzer could be decreased by as much as $1 \mathrm{~V}$ (from approximately $1.2 \mathrm{~V}-0.2 \mathrm{~V}$ ). This decrease in voltage is the result of applying natural gas to the anode side of the electrolyzer. In this technology, natural gas replaces air in the anode side while the cathode side is filled with water. Thus, this approach functions similarly to a fuel cell, generating electricity using an electrochemical reaction (Gross, 2008). NGASE is a specific type of $\mathrm{CH}_{4}$ assisted-SOFEC in which methane has been added to the anode side of the electrolyzer for hydrogen production. Initially, NGASE was based on the theory that adding methane to the anode would decrease the electrolysis voltage.

\section{Photoelectrochemical Hydrogen Production}

Both studies conducted by Wang et al. (2018) and Bicer (2017) are focused on the $\mathrm{H}_{2} / \mathrm{NH}_{3}$ production process using solar energy-based systems. Wang et al. (2018) state that if ammonia could be produced directly from nitrogen and water, powered by sunlight, in an efficient and cost-effective manner, and through a technologically advanced process, this so-called green ammonia process could change the world. Bicer (2017) concludes that the use of photoelectrochemical and catalytic hydrogen production processes are developing but a feasibility study for these methods needs to be conducted to investigate their viability. In photoelectrochemical approaches, a photosensitive material such as a semiconductor is required in which an electrodeposition system is mainly used. There are various types of deposition routes which operate at different temperatures (some higher than $100^{\circ} \mathrm{C}$ ). Wang et al. (2018) has presented various processes for ammonia production such as the study conducted by Ali et al. (2016) using solar energy. The obtained results show that the yields of solar ammonia along with the light powered nitrogen reduction processes are presently in the nmol g ${ }_{\text {cat }}^{-1} \mathrm{~h}^{-1}$ to $\mu \mathrm{mol} \mathrm{g} \mathrm{g}_{\mathrm{cat}}^{-1} \mathrm{~h}^{-1}$ range and are not enough for implementation on an industrial scale.

\section{Biological Hydrogen Production Processes}

One of the main challenges of ammonia production from biomass using a biological hydrogen production process 
TABLE 2 | A brief description of various hydrogen production processes (Wijers, 2011; Acar and Dincer, 2018).

\begin{tabular}{|c|c|c|c|}
\hline Main energy inputs & Technologies & Brief description & $\begin{array}{l}\text { State of } \\
\text { commercialization }\end{array}$ \\
\hline \multirow[t]{3}{*}{ Electrical } & Water electrolysis & $\begin{array}{l}\text { Direct current is applied in order to split water into hydrogen } \\
\text { and oxygen. }\end{array}$ & Large \\
\hline & $\begin{array}{l}\mathrm{CH}_{4} \text { assisted-Solid Oxide Fuel Electrolysis Cell } \\
\text { (SOFEC)/ Natural Gas Assisted Steam Electrolysis }_{\text {(NGASE) }^{\mathrm{a}}}\end{array}$ & $\begin{array}{l}\text { The entire process of an } \mathrm{CH}_{4} \text { assisted -SOFEC is based on } \\
\text { substituting high value electricity with cheaper methane. In } \\
\text { the } \mathrm{CH}_{4} \text { assisted-SOFEC, methane is added to the anode } \\
\text { side of the electrolyzer, the decomposition potential (voltage) } \\
\text { of water is decreased, and this results in a lower energy } \\
\text { usage and higher conversion ratio of electricity for hydrogen } \\
\text { production. }\end{array}$ & Medium/small \\
\hline & Plasma arc decomposition & $\begin{array}{l}\text { Purified natural gas (without } \mathrm{H}_{2} \mathrm{~S}, \mathrm{CO}_{2}, \mathrm{H}_{2} \mathrm{O} \text {, etc.) is passed } \\
\text { throughout the plasma arc in order to produce hydrogen and } \\
\text { carbon soot. }\end{array}$ & Large \\
\hline \multirow[t]{2}{*}{$\begin{array}{l}\text { Electrical and } \\
\text { thermal }\end{array}$} & High Temperature Electrolysis (HTE) & $\begin{array}{l}\text { Both electrical and thermal energy are utilized in order to } \\
\text { initiate, water splitting for hydrogen production. }\end{array}$ & Large \\
\hline & Hybrid thermochemical cycles & $\begin{array}{l}\text { Both electrical and thermal energy are utilized in cyclical } \\
\text { reactions. }\end{array}$ & Medium \\
\hline \multirow[t]{4}{*}{ Thermochemical } & Coal Gasification & $\begin{array}{l}\text { Conversion of coal through, thermochemical process into } \\
\text { syngas. }\end{array}$ & Large \\
\hline & Fossil fuel reforming & Fossil fuels are converted into hydrogen and carbon dioxide. & Large \\
\hline & Thermolysis & $\begin{array}{l}\text { Thermal decomposition of steam at temperatures higher } \\
\text { than } 2,226.85^{\circ} \mathrm{C} \text {. }\end{array}$ & Large \\
\hline & Thermochemical processes & $\begin{array}{l}\text {-Cyclic reactions (net reaction: water splitting into hydrogen) } \\
\text {-Thermo-catalytic conversion -Biomass conversion into } \\
\text { hydrogen }\end{array}$ & Large \\
\hline \multirow[t]{3}{*}{ Photonic } & Photo-electrochemical cells (PEC) ${ }^{a}$ & $\begin{array}{l}\text { A hybrid cell which generates voltage and current through } \\
\text { absorption of light simultaneously. }\end{array}$ & Small \\
\hline & Artificial photosynthesis & Mimicking photosynthesis process for hydrogen production. & Small \\
\hline & Photo-catalysis & Direct water splitting via photo-catalyst. & Small \\
\hline $\begin{array}{l}\text { Photonic and } \\
\text { Biochemical }\end{array}$ & Bio-photolysis ${ }^{a}$ & $\begin{array}{l}\text { Biological processes (microbes/bacteria, etc.) through } \\
\text { which water dissociates into hydrogen and oxygen in the } \\
\text { presence of light. }\end{array}$ & Small \\
\hline \multirow[t]{2}{*}{ Biochemical } & Dark fermentation $^{a}$ & $\begin{array}{l}\text { Biological processes are utilized for hydrogen production in } \\
\text { the absence of light. }\end{array}$ & Small \\
\hline & Photo-fermentation ${ }^{\mathrm{a}}$ & Fermentation process initiates through exposure to light. & Small \\
\hline
\end{tabular}

${ }^{a}$ described in A review of hydrogen production technologies for ammonia synthesis.

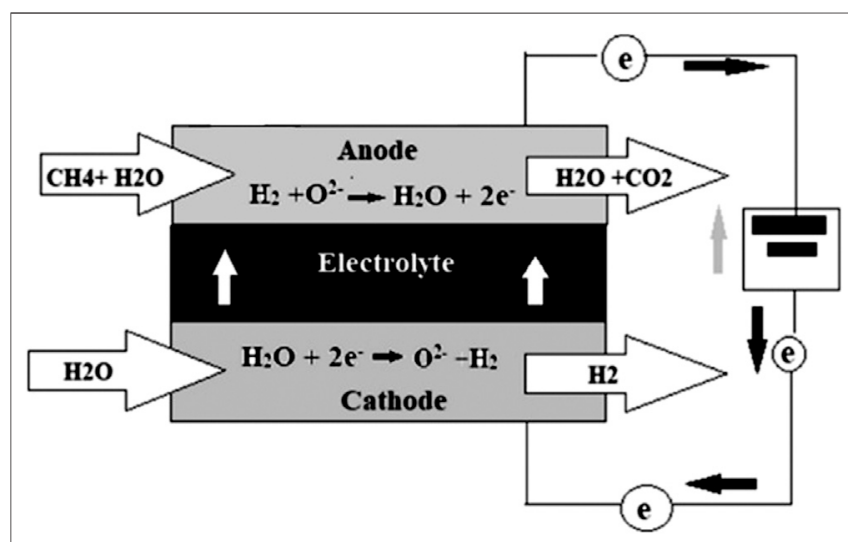

FIGURE 2 | A schematic of a $\mathrm{CH}_{4}$ assisted-SOFEC

according to Arora et al. (2016) is that ammonia production from biomass is only feasible in large volumes (global level ammonia production). Due to economies of scale, smaller plants are at a disadvantage when compared to large scale plants. Arora et al. (2016) also mentioned that transporting biomass at longer distances $(>100 \mathrm{~km})$ is not economically viable since the cost of transportation will exceed the value of energy in the biomass. This is due to the fact that biomass has a lower energy density when compared to fossil fuels. When assessing the hydrogen production processes for ammonia production this issue needs to be taken into account.

\section{Dark Fermentation}

Dark fermentation is a fermentative conversion and versatile bioprocess for production of molecular biohydrogen from various biodegradable renewable feedstocks by means of a wide range of different types of bacteria (Kothari et al., 2017; Yaswanth, 2018). This process takes place in anoxic and anaerobic conditions (in the absence of oxygen) in which, during this process, a large spectrum of anaerobic fermentative bacteria such as clostridium, facultative anaerobes such as enterobacter, and aerobes such as bacillus are involved in the fermentation process (Ghimire et al., 2015). The main mechanism for this process to take place is by the decomposition of carbohydrate rich substrates through microorganisms such as, Clostridia Sp., Enterobacter Sp. to 
hydrogen and carbon dioxide gases and other intermediate products such as Volatile Fatty Acids (VFAs) and alcohols. The main by-product of dark fermentation process are volatile fatty acids, lactic acids, alcohols, and hydrolyzed residues. These byproducts can be utilized in other biological processes for valorization through energy recovery or can be utilized as a feedstock for chemical production. Reddy (2016) states that temperature is one of the factors that affect the fermentation process which shifts the metabolic pathway to hydrogen production. These temperature ranges are: Mesophilic (operate at temperatures in the range of $25-40^{\circ} \mathrm{C}$ ), thermophilic (operate at temperatures in the range of $40-70^{\circ} \mathrm{C}$ ), extreme thermophilic (operate at temperatures in the range of $65-80^{\circ} \mathrm{C}$ ), and hyperthermophilic (operate at temperatures higher than $80^{\circ} \mathrm{C}$ ). Anaerobic bacteria which are more active in mesophilic and thermophilic temperatures are utilized for converting a wide spectrum of waste such as, sucrose, cellulose, glucose, and starches with pure strains and genetically improved cultures as seen in the reaction in Eq. 2 (Arslan et al., 2015). Enhancing the hydrogen yield from $4 \mathrm{~mol} \mathrm{H}_{2} / \mathrm{mol}$ glucose to $12 \mathrm{~mol} \mathrm{H}_{2} / \mathrm{mol}$ glucose can give the hydrogen production yields as shown in Eq. 4 (Sen et al., 2008). Improving the hydrogen yield is related to the fermentation path and final products (Ghimire et al., 2015). If the acetic acid $\left(\mathrm{CH}_{3} \mathrm{COOH}\right)$ is the byproduct of the reaction in Equation 2, a theoretical maximum of $4 \mathrm{~mol} \mathrm{H}_{2} / \mathrm{mol}$ glucose will be achieved as (Ghimire et al., 2015; Sen et al., 2008):

$$
\begin{aligned}
\mathrm{C}_{6} \mathrm{H}_{12} \mathrm{O}_{6}+2 \mathrm{H}_{2} \mathrm{O} & \rightarrow 4 \mathrm{H}_{2}+2 \mathrm{CH}_{3} \mathrm{COOH}+2 \mathrm{CO}_{2}+. . \\
\triangle G & =-206(\mathrm{~kJ} / \mathrm{mol})
\end{aligned}
$$

Furthermore, when butyrate is the sole product in the process, according to reaction in Eq. 3, a theoretical maximum of $2 \mathrm{~mol}$ $\mathrm{H}_{2} / \mathrm{mol}$ glucose is obtained as:

$$
\mathrm{C}_{6} \mathrm{H}_{12} \mathrm{O}_{6}+2 \mathrm{H}_{2} \mathrm{O} \rightarrow 2 \mathrm{H}_{2}+2 \mathrm{CH}_{3} \mathrm{CH}_{2} \mathrm{CH}_{2} \mathrm{COOH}+2 \mathrm{CO}_{2}
$$

For the complete oxidation of glucose to hydrogen and carbon dioxide as shown in reaction (4), a theoretical maximum of $12 \mathrm{~mol} \mathrm{H}_{2} / \mathrm{mol}$ glucose is acquired as (Sen et al., 2008):

$$
\begin{gathered}
\mathrm{C}_{6} \mathrm{H}_{12} \mathrm{O}_{6}+6 \mathrm{H}_{2} \mathrm{O} \rightarrow 12 \mathrm{H}_{2}+6 \mathrm{CO}_{2} \\
\triangle \mathrm{G}=-3.2(\mathrm{~kJ} / \mathrm{mol})
\end{gathered}
$$

The reaction in Eq. 4 is for complete oxidation and is based on theory and not yet applied experimentally. The actual hydrogen yield will always be lower than the theoretical yield. The main challenge with dark fermentation as cited by Sen et al. (2008) is the low hydrogen concentration which is in the range of $40-60 \%$. Increasing hydrogen yield to over $4 \mathrm{~mol}_{2} / \mathrm{mol}$ glucose makes the hydrogen economically viable. Another pathway to enhance the hydrogen yield of dark fermentation is to couple it with other processes, such as photo-fermentation, methanogenesis, Microbial Electrolysis Cell (MEC) and Microbial Fuel Cell (MFC) (Reddy, 2016; De Gioannis et al., 2013). A schematic of biochemical stages of organic waste decomposition for biogas production is shown in Figure 3. These stages are comprised of, hydrolysis, acidogenesis, and acetogenesis.

\section{Dark Fermentation Coupled With Anaerobic Digestion}

According to Liu et al. (2008) a two-stage process which combines biohydrogen and biomethane production is one possible solution for enhancing the efficiency of the dark fermentation process. Producing hydrogen solely from dark fermentation is not economically viable because of low hydrogen yields and difficult operating conditions with many variables such as maintaining the $\mathrm{pH}$, temperature, Organic Loading Rate (OLR), and specific organic loading rate at a set point. For example, experiments have been conducted on food waste for a two-stage anaerobic digestion process under different operating conditions ( $\mathrm{pH}$, temperature, organic loading rate, and Hydraulic Retention Time (HRT)) as shown in Table 3 (Cavinato and Pavan, 2011; Bolzonellaa et al., 2018). This shows that the highest Specific Hydrogen Production (SHP) rate and Specific Gas Production (SGP) rate were attained at a $\mathrm{pH}$ of 5.5 and HRT of 1.3 , which is the lowest amount when compared to the two other mentioned studies. However, the recirculation rate is the highest when compared to the other studies. The inhibition of the methanogenic activity can be accomplished by monitoring the

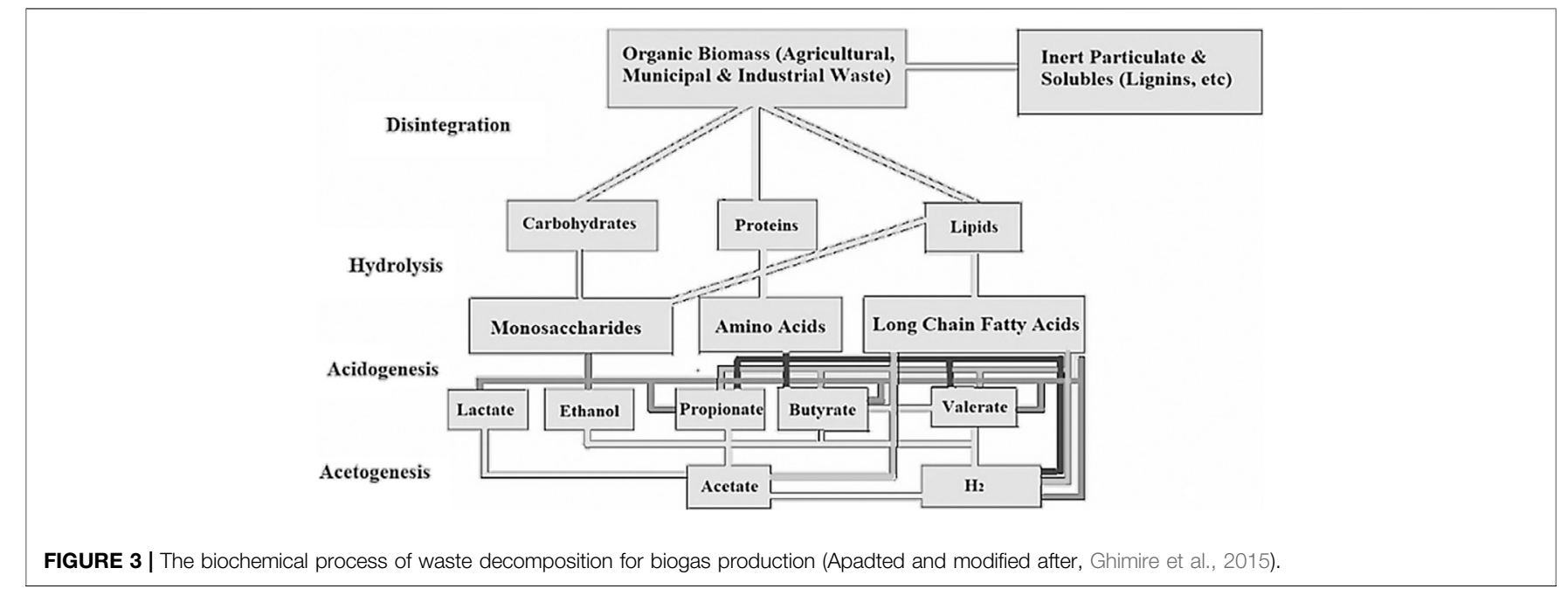


TABLE 3 | The affect of changing the recirculation rate on the two-stage dark fermentation coupled with anaerobic digestion.

\begin{tabular}{|c|c|c|c|c|c|c|c|c|c|c|c|}
\hline \multirow{3}{*}{ References } & \multirow{3}{*}{ Substrate } & \multirow{3}{*}{$\begin{array}{c}\text { Recirculation rate } \\
\text { Qr/Qin }\end{array}$} & \multicolumn{4}{|c|}{ First phase } & \multicolumn{5}{|c|}{ Second phase } \\
\hline & & & $\mathbf{T}$ & $\mathrm{pH}$ & HRT & OLR & SHP & $\mathbf{T}$ & HRT & OLR & SGP \\
\hline & & & $\overline{\left({ }^{\circ} \mathrm{C}\right)}$ & & $\overline{\text { (day) }}$ & $\begin{array}{c}\text { (kg } \\
\text { TVS/ } \\
\mathbf{m}^{3} \mathbf{d} \text { ) }\end{array}$ & $\begin{array}{c}\text { (IH } \mathrm{H}_{2} / \mathbf{k g} \\
\text { TVS) }\end{array}$ & $\overline{\left({ }^{\circ} \mathrm{C}\right)}$ & $\overline{\text { (day) }}$ & $\begin{array}{c}\text { (kg } \\
\text { TVS/ } \\
\left.\text { m }^{3} \mathbf{d}\right)\end{array}$ & $\begin{array}{c}\left(\mathrm{m}^{3} \text { biogas } / \mathrm{kg}\right. \\
\text { VS fed })\end{array}$ \\
\hline $\begin{array}{l}\text { Kataoka et al. } \\
(2005)\end{array}$ & $\begin{array}{l}\text { Food } \\
\text { waste }\end{array}$ & $0.25-0.5$ & 55 & $5-6$ & $2.5-6$ & 20.8 & $20-30$ & 55 & $18-30$ & 2.84 & 0.49 \\
\hline Chu et al. (2008) & $\begin{array}{l}\text { Food } \\
\text { waste }\end{array}$ & 2 & 55 & 5.5 & 1.3 & 38.4 & 205 & 35 & 5 & 6.6 & 0.61 \\
\hline Lee et al. (2010) & $\begin{array}{l}\text { Food } \\
\text { waste }\end{array}$ & 1 & 55 & $5.5-5.57$ & 1.9 & 39 & 83 & 55 & 7.7 & 8.4 & $0.21\left(\mathrm{CH}_{4}\right)$ \\
\hline
\end{tabular}

operating parameters such as $\mathrm{pH}$, temperature (heat treatment of inoculum can inactivate hydrogentrophic methanogens, enhance hydrogen producing bacteria, and select anaerobes that form spores.), OLR or using additives (De Gioannis et al., 2013).

Anaerobic digestion is a continuous biochemical process in which complex substrates are decomposed and digested via microbial actions and converted into biogas (Pengyu et al., 2017). The anaerobic digestion process takes place in the absence of oxygen, and occurs through four main steps: Hydrolysis, acidogenesis, acetogenesis, and methanogenesis. Biogas production from an anaerobic digestion processes is a complex mechanism where several chemical and biochemical phenomena take place. Through these steps, large organic materials that make up biomass are broken down into smaller molecules by using microorganisms in the absence of oxygen. The output from the reactions of one group of microorganisms are the substrates for the next set of reactions. As a result of the anaerobic digestion process, biomass is converted to biogas composed of: Methane, carbon dioxide, plus sulfur compounds such as hydrogen sulfide $\left(\mathrm{H}_{2} \mathrm{~S}\right)$ and some negligible traces of other gases such as ammonia, nitrogen, methane, steam, etc.

In a two-stage biohydrogen and biomethane process with household solid waste as substrate operating at $37^{\circ} \mathrm{C}$, a hydrogen yield of $43 \mathrm{ml} / \mathrm{gVS}$ added was accomplished (Liu et al., 2008). Furthermore, the methane production in a double-stage process was $21 \%$ higher than in conventional one-stage methanogenesis process since it enhanced the hydrolysis of the household waste, which proved to be the main impediment to anaerobic digestion of household solid waste. Micolucci et al. (2018) conducted an experiment on a single-stage anaerobic digestion process on food waste on a laboratory scale and reported a methane yield of $0.45 \mathrm{~m}^{3}$ $\mathrm{CH}_{4} / \mathrm{kgVS}$, with a volatile solid removal rate of $83 \%$ achieved. Anaerobic digestion was also performed in a two-phase process and showed a substantial reduction in the yield of volatile solids from $1,751 \mathrm{~kg} /$ day to $1,233 \mathrm{~kg} /$ day compared to a single stage process. The resulting energy and mass balance demonstrate that the single-phase processes were 33\% superior in terms of biogas production and energy yields (Micolucci et al. 2018). However, by comparing energy and mass balance with a two-stage reactor, the final results show that the average methane concentration for the two-phase process was $68 \%$ with a Soluble Microbial Products (SMPs) of $351 \mathrm{LCH}_{4} / \mathrm{kg}$ VS. For the single stage, methane concentration was $55 \%$ with $404 \mathrm{LCH}_{4} / \mathrm{kg}$ VS. Eventually, the author points out that the two-stage anaerobic digestion process can increase energy recovery from biomass compared to a singlestage process. Micolucci et al. (2018) also carried out an experiment in order to determine how the anaerobic digestion of an organic feedstock with a Chemical Oxygen Demand (COD) composition of almost $1 \mathrm{~g} / \mathrm{L}$ of food waste or Organic Fraction of Municipal Solid Waste (OFMSW) could be consumed in both single-stage and twostage processes. By comparing both anaerobic digestion processes, it was found that the two-stage process has a removal efficiency which is $17 \%$ higher than of a single-stage process. In addition, by applying a digestate dewatering treatment after the process, the two-stage system showed 33\% less disposable sludge. The SGP in the second-stage was higher and about $0.88 \mathrm{~m}^{3}$ biogas $/ \mathrm{kg} \mathrm{VS}$ compared to the single-phase reactor which was $0.75 \mathrm{~m}^{3}$ biogas/kg VS. The overall two-stage system efficiency for removal was $16 \%$ higher when compared to a single-phase anaerobic digestion process. This indicates resilience and high biogas production yields, using a two-stage rather than a singlephase configuration process that will significantly affect the methanogenesis process. Fermentation plays the role of pretreatment for the food waste as it enhances the conversion efficiency of the volatile fraction to biogas production (Micolucci et al. 2018).

\section{A Comparison of Various Biological Hydrogen Production Processes}

The main barriers for implementing large-scale dark fermentation for hydrogen production are: 1) low hydrogen yields, and 2) high production costs because of the high costs of feedstock. By choosing a low-cost feedstock such as biomass, including agricultural residues, and organic waste resulting from industries and municipalities, this challenge can be solved (TapiaVenegas et al., 2015). According to Kapdan and Kargi (2006), Chong et al. (2009), and Zilouie and Taherdanak (2015) this will give dark fermentation a competitive economic advantage compared to other methods currently being utilized for hydrogen production such as water electrolysis and biomass gasification. A comparison of different types of biohydrogen production methods are shown in Table 4. 
Dark fermentation is superior to other biological hydrogen production processes mentioned in this study, since it does not require light to operate. As a result, it can be implemented even in locations without accessibility to an intensive light source and the high costs associated with halogen lamps. The hydrogen production rate rises when the light intensity increases and reaches a saturation point, depending on the feedstock and microorganisms. Lack of infrared light between $750-950 \mathrm{~nm}$ wavelengths will lower hydrogen production by $39 \%$. According to Argun and Kargi (2010), both the source and the intensity of light affect the yield and rate of hydrogen gas production in photofermentation. Liu et al. (2009) carried out a study to assess the effects of light intensity and light/dark cycle on biohydrogen production with a combination of clostridium butyricum and R. faecalis RLD-53. Throughout the combination process, the highest yield was stated to be $5.374 \mathrm{~mol}-\mathrm{H}_{2} / \mathrm{mol}$-glucose.

TABLE 4 | A Comparison of different types of biological hydrogen production methods.

Technology Organisms Reactions Products $\begin{gathered}\text { Hydrogen } \\ \text { yield(mmol }(\mathbf{m m a n} \\ \mathbf{H}_{\mathbf{2}} / \mathrm{l} \text {.h) }\end{gathered}$

\begin{tabular}{llcc}
\hline Dark- & Anaerobic & $\mathrm{C}_{6} \mathrm{H}_{12} \mathrm{O}_{6}+2 \mathrm{H}_{2} \mathrm{O} \rightarrow$ & $\mathrm{H}_{2}$, \\
Fermentation & bacteria & $2 \mathrm{CH}_{3} \mathrm{COOH}+4 \mathrm{H}_{2}+2 \mathrm{CO}_{2}$ & $\mathrm{CO}_{2}$ VFA
\end{tabular}

77

configuration of
the reactor is
simple - High yield
of $\mathrm{H}_{2}$ production -
Low cost It can
produce $\mathrm{H}_{2}$
continuously
without light -This
system is an
anaerobic
process so there
is no $\mathrm{O}_{2}$
limitations -
Utilizes waste
streams - Mixed
culture friendly

Photo- $\quad$ Purple non-

Fermentation sulfur bacteria

$2 \mathrm{CH}_{3} \mathrm{COOH}+4 \mathrm{H}_{2} \mathrm{O} \rightarrow 8 \mathrm{H}_{2}+4 \mathrm{CO}_{2} \quad \mathrm{H}_{2}, \mathrm{CO}_{2} \quad 145-160$

-An extensive
range of spectral
light energy by
means of bacteria
- $\mathrm{H}_{2}$ production
from different
carbohydrates
and organic
wastes - High
hydrogen yield

Direct biophotolysis
$2 \mathrm{H}_{2} \mathrm{O}+$ (light energy) $\rightarrow 2 \mathrm{H}_{2}+\mathrm{O}_{2} \quad \mathrm{H}_{2}, \mathrm{O}_{2} \quad 0.07$

(1)

- Can produce $\mathrm{H}_{2}$ directly from
Hydrogenase (microalgae,

cyanobacteria) water or sunlight A complete carbon free process - The solar conversion energy had a growth of 10 times in comparison to trees and crops

$\begin{array}{llc}\text { Indirect bio- } & \text { Nitrogenase } & 12 \mathrm{H}_{2} \mathrm{O}+6 \mathrm{CO}_{2} \text { (light energy) } \rightarrow \\ \text { photolysis } & \text { (cyanobacteria) } & \mathrm{C}_{6} \mathrm{H}_{12} \mathrm{O}_{6}+6 \mathrm{O}_{2} \\ & \mathrm{C}_{6} \mathrm{H}_{12} \mathrm{O}_{6}+6 \mathrm{H}_{2} \mathrm{O} \text { (light energy) } \rightarrow \\ & 12 \mathrm{H}_{2}+6 \mathrm{CO}_{2}\end{array}$

\section{- $\mathrm{O}_{2}$ is a resilient} inhibitor of Hydrogenase Comparatively lower yields accomplished through this process As yields increase $\mathrm{H}_{2}$ fermentation appear

to become thermodynamically unfavorable according to Le Chatelier's principle -The product gas stream contains $\mathrm{CO}_{2}$ that needs to be separated from the $\mathrm{H}_{2}$ stream

\section{- Scaling-up the system $-\mathrm{O}_{2}$ has an inhibitory effect on hydrogenase -Low conversion efficiency approximately, $1-5 \%$}

Hawkes et al. (2007), Valdez-Vazquez and Poggi-Varaldo (2009), Tenca (2011), Akroum-Amrouche et al. (2013), Singh et al. (2015) et al. (2015)
Akroum-Amrouche et al. (2013), Tenca (2011), Singh et al. (2015), Ciranna (2014)

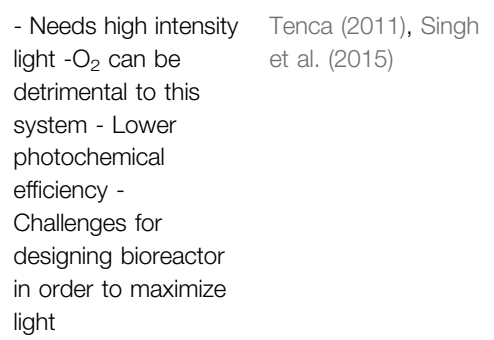

Tenca (2011), Singh et al. (2015)

-Challenges for designing bioreactor in order to maximize light $-\mathrm{O}_{2}$ has an inhibitory effect on Nitrogenase
Tenca (2011), Ciranna (2014) 
Argun and Kargi (2010) also conducted a study on the same cycle (dark fermentation/photo-fermentation) for biohydrogen production by $R$. sphaeroides-RV. Halogen lamps were found to be the most appropriate light source with a light intensity of 5 klux. There was minimal production of hydrogen when accessibility to light was below 5 klux while at light intensities higher than 5 klux no production took place. Thus, the optimum hydrogen production is achieved at precisely 5 klux. Total hydrogen yield for the dark/light cycle was stated to be $4.55 \mathrm{molH}_{2} / \mathrm{mol}$ glucose. Both dark and photo-fermentation can accept a wide spectrum of organic substrates as their feedstock to operate. Other bio-hydrogen methods such as direct and indirect biophotolysis require water for hydrogen and oxygen production. The hydrogen production rate for dark fermentation is higher compared to the technologies stated in Table 4 . The products resulting from dark fermentation according to chemical reactions in Eqs. 2, 3 are hydrogen, carbon dioxide and volatile fatty acids which can be used as the substrate for anaerobic digestion to produce biomethane. A mixture of hydrogen produced from dark fermentation along with the methane resulting from anaerobic digestion process can produce bio-hythane, a mixture of hydrogen and methane (Bolzonella et al., 2018). According to Table 4, as cited by Tenca (2011), Valdez-Vazquez and Poggi-Varaldo (2009), Hawkes et al. (2007), and Akroum-Amrouche et al. (2013), it can be concluded that among the biohydrogen production methods, dark fermentation is the most efficient biological technology when coupled with methods mentioned for hydrogen production required for ammonia synthesis.

\section{A REVIEW OF SUSTAINABLE TECHNOLOGIES FOR AMMONIA PRODUCTION}

Due to the important role of ammonia as a fertilizer in the agricultural industry and its promising prospects as an energy carrier, many studies have recently attempted to find the most environmentally benign, energy efficient, and economically viable production process for ammonia synthesis. There are a number of sustainable technologies for ammonia production, such as electrochemical ammonia production, Non-Thermal Plasma (NTP) synthesis for ammonia production, and nitrogenasemotivated peptide-functionalized catalyst for electrochemical ammonia production. These technologies will be assessed in Electrochemical Ammonia Production, Non-thermal Plasma (NTP) Synthesis for Ammonia Production, and Nitrogenase Motivated Peptide-functionalized Catalyst for Electrochemical Ammonia Production respectively.

\section{Electrochemical Ammonia Production}

Electrochemical ammonia production technologies are divided into three categories based on the operational temperature range of the electrochemical cell: Low temperatures, under $100^{\circ} \mathrm{C}$, intermediate temperature in the range of $100-400^{\circ} \mathrm{C}$ and high temperatures in the range of $400-750^{\circ} \mathrm{C}$ (Amar et al., 2011). According to Soloveichk (2017), the advantages of electrochemical technology compared to thermochemical (Haber-Bosch) are in four major areas:

(1) Higher efficiency, which permits energy saving.

(2) Higher selectivity, meaning that less purification is required.

(3) Lower temperatures and pressures, resulting in reduced Capital Expenditure (CAPEX) costs through lower balance of plant.

(4) Modularity, which makes these plants suitable for small to medium scale utilization.

\section{Electrochemical Synthesis of Ammonia Through Low Temperatures $\left(<100^{\circ} \mathrm{C}\right)$}

For temperatures lower than $100^{\circ} \mathrm{C}$, a cell with a potassium hydroxide $(\mathrm{KOH})$ solution as electrolyte and Nafion as the separation membrane, a platinum $(\mathrm{Pt})$ anode and a ruthenium $(\mathrm{Ru}) / \mathrm{C}$ cathode are utilized in order to synthesize ammonia (Kordali et al., 2000). The maximum production rate for this is stated as ca. $2 \times 10^{-11} \mathrm{~mol} \mathrm{~s}^{-1} \mathrm{~cm}^{-2}$, operating at the temperature of $90^{\circ} \mathrm{C}$, resulting from steam and nitrogen with a $0.2-1 \%$ Faradic Efficiency (FE), which is defined as the proportion of protons that are converted to ammonia by migrating throughout the electrolyte. The electrolytes which are utilized for low temperature electrochemical ammonia synthesis in place of polymeric electrolyte membrane are, sulfonated-poly-sulfone (SPSF) membranes, Nafion membranes or $\mathrm{NH}_{4}^{+}$in substitute to Nafion membranes (Lan et al., 2013). Xu et al. (2009) investigated a maximum ammonia production rate of $1.13 \times 10^{-8} \mathrm{~mol} \mathrm{~s}^{-1} \mathrm{~cm}^{-2}$ operating at a low temperature of $80^{\circ} \mathrm{C}$ with an applied voltage of $2 \mathrm{~V}$ by means of a Nafion membrane (as the electrolyte), a Ni-doped SDC (Ni-SDC), $\mathrm{NiO}^{-} \mathrm{Ce}_{0.8} \mathrm{Sm}_{0.2} \mathrm{O}_{2-\delta}$ anode and $\mathrm{SmFe}_{0.7} \mathrm{Cu}_{0.3-}$ ${ }_{\mathrm{x}} \mathrm{Ni}_{\mathrm{x}} \mathrm{O}_{3}(\mathrm{x}=0-0.3)(\mathrm{SFCN})$ cathode. Hydrogen and nitrogen were used as the reactants in the process operating at atmospheric pressure. High faradic efficiency, above $90 \%$ (90.4\%) was accomplished. This figure is higher than was reported by other studies, when testing low temperature ammonia synthesis processes. As stated by Lan et al. (2013), ammonia is a weak base which can react with acidic membranes such as Nafion resulting in a reduction in proton conductivity. As a result, it has been stated that Nafion membrane utilization converted from $\mathrm{H}^{+}$form to the $\mathrm{NH}_{4}{ }^{+}$form via exposing the cell to a flow comprised of ammonia solution with a faradic efficiency lower than 1\%. Lan et al. (2013) carried out an experiment for ammonia production from air and water at ambient temperatures. The low faradic efficiency of this experiment is due to the type of catalyst used $(\mathrm{Pt})$ which is not the most appropriate choice for nitrogen reduction. Lapina et al. (2013) states that air can be used in place of pure nitrogen, although some authors claim that oxygen poisons the catalyst used for the ammonia synthesis process (Marrony, 2015). Lapina et al. (2013) specifies that the effect of using pure nitrogen or air (as the nitrogen source) on faradic efficiency has not been reported in any study. Lapina et al. (2013) also state that at low temperatures, ammonia production from nitrogen and hydrogen is spontaneous and, as a result, the 
minimum voltage needed is negative, meaning that there is no need to apply a voltage. Although in reality, applying voltage is required to overcome the electrode over-potential and ohmic losses in the electrolyte, while a limited current pass throughout the cell. If water is utilized in place of hydrogen, an applied voltage is needed to drive the reaction (Lapina et al., 2013).

\section{Electrochemical Synthesis of Ammonia Through High Temperatures $\left(>400^{\circ} \mathrm{C}\right)$}

For high temperatures, in the range of $400-750^{\circ} \mathrm{C}$, a solid-state proton conductor or oxide ion conductor is utilized as the electrolyte for electrochemical ammonia synthesis. Several studies have been conducted on the utilization of both proton ion conductors and oxide ion conductors such as, Marnellos et al. (2000) and Skodra and Stoukides (2009). Skodra and Stoukides produced ammonia via steam and nitrogen at temperatures in the range of 450-700C using ruthenium as the catalyst supported on silver $(\mathrm{Ag})$ or palladium $(\mathrm{Pd})$ as the cathode. In their study, $\mathrm{SrCe}_{0.95} \mathrm{Yb}_{0.05} \mathrm{O}_{3-\delta}$ as the proton conductor or $\mathrm{ZrY}_{0.92} \mathrm{Y}_{0.08} \mathrm{O}_{2-\delta}$ as oxide-ion conductor were used as the electrolytes. For both, the production rates are respectively: $10^{-12}$ and $10^{-11} \mathrm{~mol} \mathrm{~s}^{-1} \mathrm{~cm}^{-2}$ with faradic efficiency of $0.01 \%$. The faradic efficiency stated by Marnellos and Stoukides (1998) and Marnellos et al. (2000) was $90 \%$, which was accomplished by using of hydrogen and nitrogen in a cell with $\mathrm{SrCe}_{0.95} \mathrm{Yb}_{0.05} \mathrm{O}_{3-\delta}$ electrolyte and palladium electrodes (Lapina et al., 2013). In all the mentioned studies, the ionic currents, meaning the rates of ion migration throughout the electrolyte, were at the same scale. The ammonia production rates were approximately three orders of magnitude lower in the experiment conducted by Skodra and Stoukides (2009). One of the major downsides of high temperature ammonia synthesis is that it can decompose thermally after production. Liu et al. (2006) have reported ammonia production rates in the range of $7.2-8.2 \times$ $10^{-9} \mathrm{~mol} \mathrm{~s}^{-1} \mathrm{~cm}^{-2}$ operating in the temperature range $400-800^{\circ} \mathrm{C}$ by means of $\mathrm{Ce}_{0.8} \mathrm{M}_{0.2} \mathrm{O}_{2-\delta}(\mathrm{M}=\mathrm{La}, \mathrm{Y}, \mathrm{Gd}, \mathrm{Sm})$ as electrolyte and $\mathrm{Ag}-\mathrm{Pd}$ as electrodes. These authors claimed that a faradic efficiency of $100 \%$ was achieved. There are other studies such as Wang et al. (2011) using the same type of electrode (Ag-Pd) doped with barium operating in the temperature range $400-600^{\circ} \mathrm{C}$ with the ammonia production rate reported to be in the range of $1-5 \times 10^{-9} \mathrm{~mol} \mathrm{~s}^{-1} \mathrm{~cm}^{-2}$ and with the faradic efficiency of $40-50 \%$. Amar et al. (2011) have also utilized carbonate-oxide composite electrolytes operating in the temperature range $400-450^{\circ} \mathrm{C}$, with the highest ammonia production rate reported to be $5.39 \times 10^{-9} \mathrm{~mol} \mathrm{~s}^{-1} \mathrm{~cm}^{-2}$, operating at the temperature of $450^{\circ} \mathrm{C}$ with a $\mathrm{La}_{0.6} \mathrm{Sr}_{0.4} \mathrm{Fe}_{0.8} \mathrm{Cu}_{0.2} \mathrm{O}_{3-\delta}-\mathrm{Ce}_{0.8} \mathrm{Sm}_{0.2} \mathrm{O}_{2-\delta}$ composite cathode, $\mathrm{NiO}-\mathrm{Ce}_{0.8} \mathrm{Sm}_{0.2} \mathrm{O}_{2-\delta}$ anode, and composite $\mathrm{Ce}_{0.8} \mathrm{Sm}_{0.2} \mathrm{O}_{2-\delta}$ $\mathrm{Li}_{2} \mathrm{CO}_{3}-\mathrm{Na}_{2} \mathrm{CO}_{3}-\mathrm{K}_{2} \mathrm{CO}_{3}$ as the electrolyte.

\section{Different Types of Polyelectrolytes Utilized for Electrochemical Ammonia Synthesis}

There are four main classifications of electrolytes utilized for electrochemical ammonia synthesis which are: 1) liquid electrolyte operating near room temperature; 2) molten salts operating at intermediate temperatures of $180-500^{\circ} \mathrm{C}$; 3) composite membranes comprised of a conventional solid electrolyte mixed with a low melting salt, operating in the temperature range of $300-700^{\circ} \mathrm{C}$; 4) solid-state electrolytes with an extensive operating temperature range from approximately ambient temperature to $700-800^{\circ} \mathrm{C}$ which depends on the type of electrolyte membrane utilized (Hughes et al., 2015; Bicer and

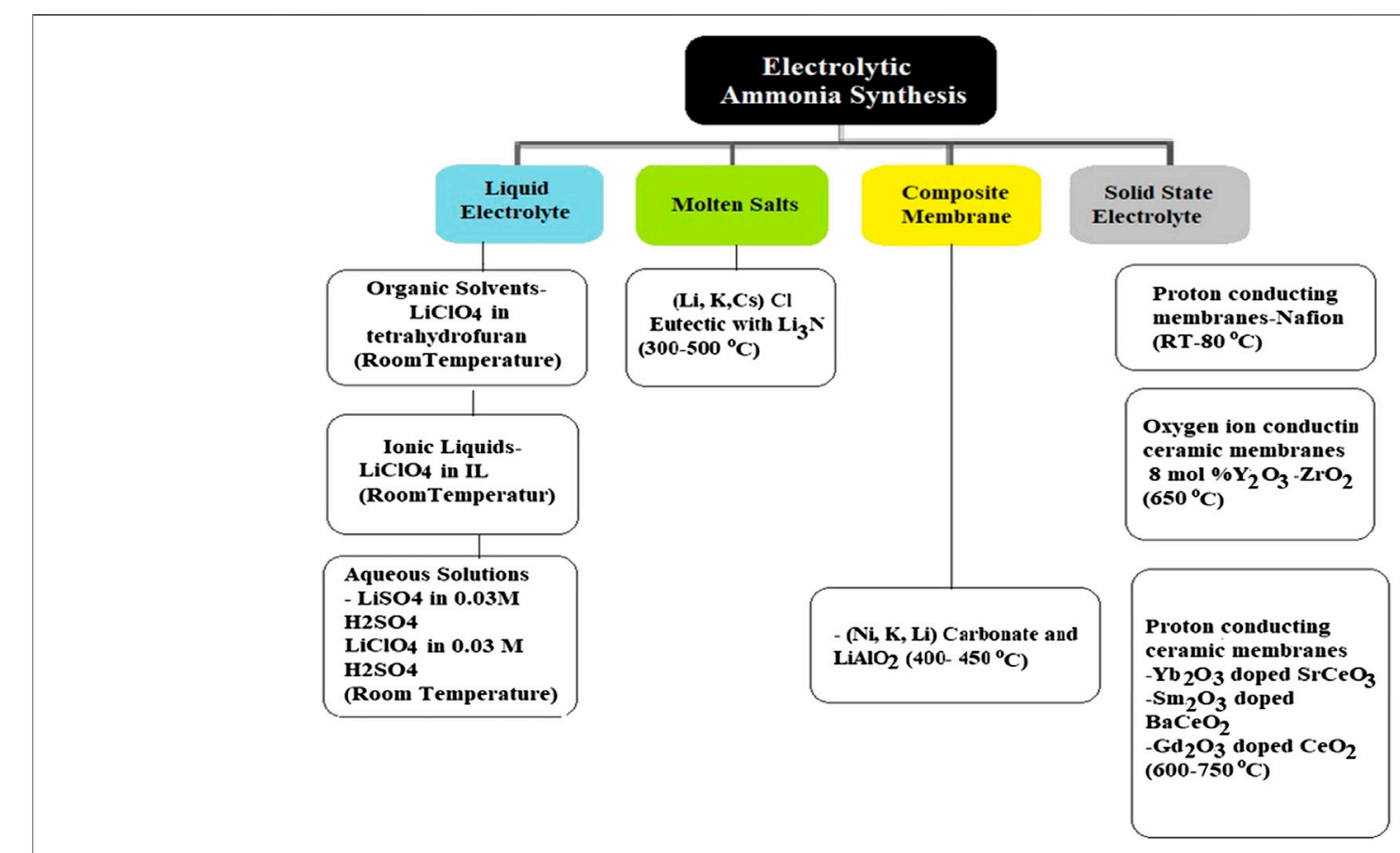

FIGURE 4 | Different electrolytic routes for ammonia production. 
Dicer, 2018). These electrolytic ammonia production routes are presented in Figure $\mathbf{4}$ with brief descriptions.

There are several issues associated with the catalytic process for ammonia synthesis such as, low conversion, severe environmental pollution, and high energy usage. These problems are addressed by utilizing electrolytic ammonia synthesis technologies (Amar et al., 2011). There are a number of problems associated with electrolytic ammonia synthesis such as low production rates (usually in the range of $10^{-13}-10^{-8} \mathrm{~mol}$ $\mathrm{s}^{-1} \mathrm{~cm}^{-2}$ ) except for polymer electrolyte membranes which have a $10^{-8} \mathrm{~mol} \mathrm{~s}^{-1} \mathrm{~cm}^{-2}$ production rate and instability issues of the acidic electrolyte membrane.

Current studies suggest that electrolytic reduction of nitrogen using heterogeneous catalysts has been shown to be a green and sustainable pathway for ammonia production. In this process, ammonia is synthesized from water and nitrogen powered by renewable energy sources such as solar/wind under ambient conditions. The most important elements for producing ammonia through electrochemical Nitrogen Reduction Reaction (NRR) system powered by renewable energy sources are electrocatalysts. Electrocatalysts need to be designed for optimizing the mass transport, physisorption, chemisorption, and transfer of electrons and protons to reach high selectivity and catalytic performance. Although producing ammonia through NRR is a promising sustainable technology, many of the electrocatalysts for this system have a low faradic efficiency and ammonia yield rate compared to the conventional HaberBosch process (Guo et al., 2019).

\section{Non-Thermal Plasma Synthesis for Ammonia Production}

The volatility of fossil fuel prices, which are the main feedstock for the Haber-Bosch process, the need for large volumes of fossil fuels to power the process, and the high operational costs associated with its high operating pressure (150-300 bar) and temperature $\left(400-500^{\circ} \mathrm{C}\right)$ make this technology energy intensive (Peng et al., 2018). According to Peng et al. (2018), all the stated factors make the current process for ammonia production not appropriate for implementation on a small and decentralized scale. They conducted research on plasma-assisted ammonia synthesis, using a NTP, which operates at low temperatures (approximately $50^{\circ} \mathrm{C}$ ) and pressure conditions of approximately $1 \mathrm{~atm}$. This technology is able to address some of the problems associated with the Haber-Bosch process, such as, the high capital costs, fossil fuel usage, etc. The two most critical challenges of this technology as stated by Peng et al. (2018) are: 1) nitrogen gas fixation and 2) back reactions. In addition, the state that the conversion and efficiency rates need to be improved as this technology is still in the research and development stage (available on a small scale). However, the advantages of this system according to Peng et al. (2018) are that the NMP process does not require fossil fuels to operate, has low capital cost and has a small physical foot print. This process is more compatible for distributed ammonia production in local farms and ammonia can be produced constantly at atmospheric pressure through this method. The West
Virginia University Research Corporation (WVURC) is also developing a technology known as WVU. This technology converts renewable electricity, water, and air into ammonia by means of plasma excitation (WVU, 2016). In this process, the aim is to lower the operational pressures and temperatures which will lead to the production of ammonia at five times the conversion rate of the Haber-Bosch process. According to WVU (2016), this method differs from both electrochemical conversion processes such as Solid State Ammonia Synthesis (SSAS) and catalytic processes such as the Haber-Bosch process. In this form of physical activation, the microwave plasma process is able to activate both nitrogen and hydrogen, and produce ions and free radicals that react over the catalyst surface in order to produce ammonia. One of the benefits of this process is that under the appropriate conditions, microwave heating is able to heat the catalyst selectively to reach the required temperature without the need for reactions to take place and without heating the bulk environment. This arrangement of a catalyst with a high temperature within a cool environment results in lower overall reaction temperatures and enhances the energy efficiency. In addition, as stated by WVU (2016), the simplified design of this process is due to its low operational pressure. The low operational pressure of this process enables it to be a better fit with renewable energy sources, since the system is reportedly able to be turned on and off easily.

\section{Nitrogenase Motivated Peptide-Functionalized Catalyst for Electrochemical Ammonia Production}

Ammonia is produced in nature through nitrogenase enzymes, with an efficiency of approximately 75\%. As the efficiency of ammonia production in nature is very high, electrochemists have attempted to utilize these enzymes for industrial applications of ammonia synthesis such as in the study conducted by Loney et al. (2017). According to this study, electrochemical ammonia synthesis is a promising technology but its low operating temperature and pressure conditions have shown efficiencies of less than $1 \%$, which would require a catalyst for enhancing the efficiency of ammonia production. Furthermore, peptide functionalized catalysts were developed and tested in an Anion Exchange Membrane (AEM)-based system. The material used in this catalyst shows promising results compared to conventional catalyst approaches. Szymanski and Gellett (2017) also state that the electrochemical processes are modular and are able to be coupled with renewable energy sources such as solar and wind and also have the capability to function at relatively lower temperatures and pressures compared to the larger scale conventional ammonia production processes. For this reaction to occur, a catalyst is required that is selective to ammonia production. In order to address this issue, Szymanski and Gellett (2017) conducted a feasibility study in order to enhance ammonia selectivity by tailoring a nanoparticle catalyst morphology and utilizing peptides resulting from nitrogenase (a naturally occurring nitrogen splitting enzyme) in order to direct the desired reaction. Greenlee et al. (2017) addressed the selectivity 
issues for electrochemical nitrogen reduction by designing nanoparticle catalysts, such as non-precious metal-based catalysts comprised of iron and nickel, that are bimetallic materials and are theoretically predicted to lead to optimum surfaces for nitrogen reduction. Greenlee et al. (2017) also reported that they are able to control the local surface environment of the catalyst by means of specifically structured short chain peptide series that had been inspired by the structure of the nitrogenase enzyme.

\section{ENVIRONMENTAL IMPACT OF VARIOUS AMMONIA PRODUCTION PROCESSES}

Life Cycle Assessment (LCA) is a primary technique used to support decision making for sustainable development in production. A number of studies have been conducted on the comparative LCA of sustainable ammonia production pathways. These studies include Bicer et al. (2016) on a comparative LCA of different ammonia production methods and Frattini et al. (2016) on a system approach in energy evaluation of different renewable energy sources integrated into ammonia production plants. The same approach (producing an LCA) was carried out by Tallaksen and Reese (2013) and Arora et al. (2018), both selecting the Functional Unit of $1 \mathrm{~kg}$ of ammonia for its production using fossil fuels and renewable sources. Tallaksen and Reese (2013) compared both approaches in terms of the usage of energy and carbon emissions. However, Arora et al. (2018) identified the carbon emissions and costs related to ammonia production. The system boundary by Tallaksen and Reese in their study for ammonia production powered by wind was comprised of wind power, water electrolyzer, hydrogen compression, nitrogen separation/compression, ammonia production, and ammonia storage (Matzen et al., 2015). However, the system boundary selected by Arora et al. was more detailed in comparison. Arora et al. estimated the emissions resulting from coal mining, biomass harvesting, transportation, electricity production, and utilities in their study, and also conducted an LCA on ammonia production. Concluded that the Global Warming Potential (GWP) of coal gasification with $4.22 \mathrm{~kg} \mathrm{CO} \mathrm{CO}_{2 \mathrm{eq}} / \mathrm{kg} \mathrm{NH} \mathrm{NH}_{3}$ is the highest when compared to biomass gasification with $1.2 \mathrm{~kg} \mathrm{CO} \mathrm{CO}_{2 \mathrm{eq}} / \mathrm{kg} \mathrm{NH} \mathrm{NH}_{3}$, while SMR of natural gas falls in between with GWP of $2.81 \mathrm{~kg}$ $\mathrm{CO}_{2 \mathrm{eq}} / \mathrm{kg} \mathrm{NH}_{3}$. However, in this study, coal gasification to ammonia production was priced lower than the other processes discussed due to lower energy consumption, feedstock cost, and not consuming significant amounts of energy related to carbon dioxide stream compression. Makhlouf et al. (2015) also conducted an LCA and presented the results for production of 1 tonne of ammonia by SMR of natural gas in Algeria. The results indicated that the GWP is high, which is due to the amount of GHG emissions of $1.44 \mathrm{t} \mathrm{CO}_{2 \mathrm{eq}} / \mathrm{t}$ of $\mathrm{NH}_{3}$. Although this figure $\mathrm{t}$ $\mathrm{CO}_{2 \mathrm{eq}} / \mathrm{t}$ of $\mathrm{NH}_{3}$ ) is lower when compared to the results reported by Arora et al. (2018) for the production of ammonia from natural gas, which is said to be $2.81 \mathrm{t} \mathrm{CO}_{2 \mathrm{eq}} / \mathrm{t}$ of $\mathrm{NH}_{3}$ ) of GHG emissions. The system boundary for the LCA differs in the two studies. In Makhlouf et al., the system boundary consists of an upgrading stage along with a SMR process for ammonia synthesis. In addition, Makhlouf stated that when calculating the GHG balance, only the amount of natural gas utilized as fuel was considered and the amount of process gas was not taken into account. The outcome of the study shows that the energy requirement for ammonia production by the SMR of natural gas in Algeria was $25.16 \%$ higher than of other locations globally. This figure was said to be $51.9 \times 10^{3} \mathrm{MJ} / \mathrm{t}$ of ammonia while the global energy requirement for ammonia production is reported to be $41.5 \times 10^{3} \mathrm{MJ} /$ tonne (IEA, 2007). Arora, et al. conducted their LCA in order to compare the GWP of biomass to ammonia production processes through three different configurations, SMR, Auto-thermal Reforming (ATR) and carbon dioxide reforming. All three configurations were modeled and compared for utilization of three different types of biomass feedstock: Straw, bagasse and wood, in order to understand the effects of their composition on supply chain, economics, and environmental factors for ammonia production. Their study emphasized that GWP will be lowered if biomass is used as the feedstock for ammonia synthesis. Among the three types of biomass used for ammonia synthesis in the study, bagasse has the lowest GWP followed by wood and straw pellets. However, Arora et al. (2017) concluded that the GWP of straw used as biomass for ammonia production is similar to the GWP of natural gas for ammonia synthesis when there is no electricity cogeneration. Among the three different types of biomass, wood has the highest ammonia production rate. Arora et al. (2017) conducted a Multi-Objective Optimization (MOO) showing that one route for reducing the GWP of biomass to ammonia process can be through the utilization of a proportion of the produced syngas resulting from biomass gasification which can also be used for electricity production. With this solution, the discharge of GHG emissions from the use of electricity will be lowered. However, this strategy will decrease the amount of ammonia produced, resulting in an increased output product price. Arora et al. compared the trade-off between ammonia production and electricity generation for three different types of feedstock and different results were obtained. All variables such as the specific type of biomass, economics, and the environmental profile correlate to a specific location. As reported for the production of a specific amount of ammonia using the same production process, the amount of water depletion when using bagasse is higher compared to using wood as the feedstock. For example, when using the SMR process for ammonia production, the amount of water depletion by means of bagasse is said to be $2.95 \times 10^{-2} \mathrm{~m}^{3}$ while wood was reported to be $3.3 \times 10^{-3} \mathrm{~m}^{3}$.

Tallaksen and Reese (2013) conclude that hydrogen production through water electrolysis powered by wind requires approximately $60 \mathrm{GJ}$ of electricity/tonne $\mathrm{NH}_{3}$. This total energy is considerably higher compared to conventional fossil fuel-based ammonia production, which is $36.6 \mathrm{GJ}$ energy for production of 1 tonne of ammonia. According to Tallaksen and Reese (2013) the process requires less fossil energy since the system operates with wind power, resulting in lower GHG emissions when compared to running the system from the grid which was reported as $58.7 \mathrm{GJ} /$ tonne. Whereas, Frattini et al. (2016) concludes that producing ammonia from renewable energy sources increases the security of supply. Both studies agree that ammonia production from renewable energy sources results in lower carbon dioxide emissions. 
Bicer et al. (2016) conducted this study on four different ammonia production methods by the Haber-Bosch process using a feedstock of electrolytic hydrogen. They concluded: 1) ammonia production from a water electrolyzer powered by biomass and municipal waste offers a reliable alternative for distributed ammonia production facilities and can increase fertilizer production; 2) municipal waste-based ammonia production can be considered as one the most environmentally benign methods among the proposed processes, since it has the lowest abiotic depletion, global warming, and human toxicity values 3) the renewable sources with their improved efficiency are able to lower the overall environmental footprint and can replace the current fossil fuel-based centralized ammonia production facilities. Frattini et al. (2016) on the other hand compared the efficiency of the energy flows and GHG emissions for the HaberBosch ammonia production process by means of different hydrogen production pathways. Through this study they assessed three scenarios for renewable hydrogen production: 1) biomass gasification, 2) electrolysis of water and 3) biogas reforming. They compared these technologies with the conventional SMR of natural gas. They concluded that ammonia has the capability to be produced through an efficient manner using renewable energy sources, leading to an alternative method of a distributed, efficient, and sustainable ammonia production process. This results in a decrease in carbon dioxide emissions and costs, and an increase in production output. Moreover, this process allows for storing of renewable energy as a seasonal energy vector which has a high energy density with low emissions.

Frattini et al. (2016) made a clear case for the advantages of electrolytic hydrogen production compared to biomass gasification/biogas reformation in regards to the energy flux of each system. In regards to energy flows, they concluded that all proposed processes, including the conventional methods of SMR, have the same primary power usage within the range of $14-15 \mathrm{kWh} / \mathrm{kg} \mathrm{NH}$. New configurations have no effect on the amount of primary energy utilized for ammonia synthesis. This demonstrates that applying renewable energy does not limit the efficiency of the process. They made an explicit case for the advantages of electrolytic hydrogen production in comparison to biomass gasification or biogas reformation. Both studies aim to quantify the costs and advantages of integrating the HaberBosch process with a renewable hydrogen feedstock resulting from biomass gasification, electrolysis of water operating by solar, wind, hydropower, nuclear power, and biomass. In summary, both projects investigated the carbon intensity of ammonia production. However, Bicer et al. (2016) expands its area of research to a full LCA, including GWP, Human Toxicity, and abiotic depletion, while the study conducted by Frattini et al. (2016) emphasized primarily on energy efficiency. The LCA study by Tallaksen and Reese (2013) on the other hand was more focused on environmental issues rather than raw material depletion. Another study conducted by Bicer and Dincer (2018) highlights the advantages of ammonia utilization in transportation (passenger cars) and power plants by evaluating different environmental impacts including: GWP, acidification, abiotic depletion, and ozone layer depletion. In this study ammonia is produced using water electrolysis in an electrochemical reactor using molten salt electrolyte powered by wind energy. According to Bicer and Dincer (2018) the GHG emissions for vehicles utilizing the aforementioned ammonia is approximately $37 \%$ lower compared to gasoline powered vehicles. This also applies to the production of about $0.27 \mathrm{kWh}$ electricity in ammonia fired power plants compared to power plants operating on natural gas, resulting in approximately $64 \%$ less $\mathrm{kg} \mathrm{CO}_{2 \mathrm{eq}}$. Both Frattini et al. (2016) and Bicer and Dincer (2018) conclude that electrolytic hydrogen production for ammonia synthesis is advantageous from the environmental point of view due to the potential absence of GHG emissions. Bicer and Dincer (2018) also makes an explicit case for replacing conventional fuels with carbon free ammonia, thereby significantly reducing the GHG emissions associated with the transportation and power generation sectors.

\section{ADDRESSING PROBLEMS ASSOCIATED WITH CURRENT RENEWABLE TECHNOLOGIES FOR AMMONIA PRODUCTION}

There is a lack of research on the environmental and economic impact of water usage in the production of ammonia which is assessed in this section.

\section{Water Intensity}

Many studies have been conducted on sustainable ammonia production and mainly focus on water electrolyzers powered by renewable technologies such as solar and wind. These studies include one conducted by Soloveichk (2017) and a series of different processes that was compiled by Wang et al. (2018), Service (2018), and Hughes et al. (2015). There is a crucial research gap on environmental and economic aspects of sustainability when assessing water consumption in the production of ammonia in these reviews. In order to operate, these processes require a constant water supply while considering the implications of the increasingly severe worldwide water crisis. The critical inputs for electrolysis are electricity and deionized water. In general, a water electrolyzer requires pretreated, high purity water for its operation (Mehmeti et al., 2018). Moreover, for production of 1 tonne of hydrogen, 9 tonnes of water is required. The major implications of water consumption in various hydrogen production processes and the effects associated with water on the environment are important factors that have been assessed in the study conducted by, Mehmeti et al. (2018) by means of LCA. Studies conducted by Alcamo et al. (2007), Distefano and Kelly (2017), Ercin and Hoekstra (2014), and Hoekstra et al. (2011) have shown that there will be a significant increase in water scarcity in the next few decades and this will result in problems for food security, environmental sustainability, and economics. However, it must be noted that water scarcity is dependent on local availability. According to Mehmeti et al. (2018), SMR and water electrolysis cause the most damage to the environment since these processes use high quality water (lowdissolved-solid concentrations/deionized water) for operation. Morgan (2013) also conducted a techno-economic feasibility study on an ammonia production plant powered by offshore 
TABLE 5 | Key consumption and GHG emissions for renewable and conventional ammonia production technologies to produce 1 tonne of ammonia.

\begin{tabular}{|c|c|c|c|c|c|c|}
\hline Technology & $\begin{array}{c}\text { Water } \\
\text { consumption } \\
(\mathbf{k g ~ H} \mathrm{O} / \mathrm{t} \mathrm{NH} \text { ) }\end{array}$ & $\begin{array}{c}\text { (kg of } \\
\mathrm{CO}_{2} \\
\text { emitted/t } \\
\left.\mathrm{NH}_{3}\right)\end{array}$ & $\begin{array}{c}\text { Energy (electricity } \\
\text { and heat } \\
\text { consumption } \\
(\mathrm{kWh} / \text { tonne } \\
\left.\mathrm{NH}_{3}\right)\end{array}$ & $\begin{array}{c}\text { Efficiency } \\
\%\end{array}$ & $\begin{array}{l}\text { Capital cost } \\
\text { per ton/day } \\
\mathrm{NH}_{3} \text { capacity }\end{array}$ & References \\
\hline $\begin{array}{l}\text { Steam methane reforming coupled } \\
\text { with Haber-Bosch }\end{array}$ & са. 0.656 & ca. 1.8 & ca.9,500 & 61-66\% & 500,000 & $\begin{array}{l}\text { Ganley et al. (2015), Soloveichik } \\
\text { (2017a), (Elgowainy, 2015) }\end{array}$ \\
\hline $\begin{array}{l}\text { Water electrolysis coupled with } \\
\text { Haber-Bosch powered by solar/ } \\
\text { wind }\end{array}$ & ca.1.588 & negligible & ca. 12,000 & $\sim 54 \%$ & 750,000 & $\begin{array}{l}\text { Pfromm (2017), Ganley et al. (2015), } \\
\text { Will and Lukas (2018), Soloveichik } \\
\text { (2017a) }\end{array}$ \\
\hline
\end{tabular}

wind. The study reported that for the production of 300 tonnes of ammonia, 476 tonnes of distilled water are required. The ratio of the treated water required per tonne of ammonia (excluding the water needed for the cooling tower) is approximately 1.6. This figure is also reported by Will and Lukas (2018) when assessing an ammonia production plant using water electrolysis powered by renewables (solar, wind, and hydro) energy. For a 50 tonne/day ammonia production plant, $20 \mathrm{MW}$ power is needed and for a 300 tonne/ day of ammonia plant, $120 \mathrm{MW}$ is required. Based on Will and Lukas's study, the water loss from the cooling towers is said to be in the range of approximately $1-1.5 \%$ of the total input water. This shows that for the production of approximately 1 tonne of ammonia, 2.45 tonnes of water is required when taking into account the amount of water loss of cooling towers. While Will and Lukas (2018) report a portion of the input water is lost through cooling towers, when using AWARE impact assessment method in LCA, the water utilized for cooling towers is counted as $100 \%$ loss. According to the study conducted by Morgan (2013), a water desalinization system is incorporated into its process for production of purified water required for ammonia synthesis. The use of desalination systems is energy intensive and detrimental to ocean biodiversity and marine life (Peterson, 2017). In 2016, the amount of ammonia produced was reported to be 146 million tonnes globally. Based on this data, to produce the same amount of ammonia through water electrolysis, 233.6 million tonnes of water is required. While a water electrolyzer coupled with renewable technologies as discussed above requires high volumes of water for its operation, the conventional ammonia production process, which is SMR coupled with Haber-Bosch processes, is also relatively water intensive requiring approximately $0.656 \mathrm{~kg}$ of water to produce $1 \mathrm{t}$ of ammonia. However, this figure is lower than the aforementioned methods for ammonia production. Table 5 shows that SMR coupled with Haber-Bosch process is the most carbon intensive technology with $1.8 \mathrm{~kg} \mathrm{CO}_{2} / \mathrm{t} \mathrm{NH}_{3}$ when compared to the other technology. Water electrolysis is the most water (ca. $1.588 \mathrm{~kg} \mathrm{H}_{2} \mathrm{O} / \mathrm{tNH}_{3}$ ) and energy (ca. 12,000 kWh/tonne $\mathrm{NH}_{3}$ ) intensive among the processes being reviewed.

\section{CONCLUSION}

Ammonia can play the role of a fuel for energy storage as well as its primary use as the main ingredient for fertilizers, transport fuels, and many other applications. However, sustainable routes for its production are needed. As hydrogen is the main feedstock for ammonia synthesis, a review of various sustainable hydrogen and ammonia production processes has been carried out. In addition, an assessment of different studies on the environmental performance of ammonia production through LCA has been conducted.

The review of ammonia production technologies shows that current processes are either multistage, energy or carbon intensive, or require significant amounts of water resources to operate. Identifying greener pathways (low carbon, low water, and low energy usage) for ammonia production is important to ensure food security and its application in energy storage. After reviewing several studies, there seems to be a lack of focus on processes that aim to reduce the amount of water required for sustainable ammonia production. However, there are a number of studies that have assessed the effect of water usage in different ammonia production processes (SMR and water electrolysis) by focusing on food security, environmental sustainability, and economics through conducting LCA. Two mature technologies, SMR and water electrolysis, both coupled with Haber-Bosch and powered by renewable technologies are compared in this study. The former consumes less water while having higher GHG emissions and the latter emits less GHGs with higher water consumption. Of course, each hydrogen production technology has its pros and cons, the selection of these requires various criteria that would be specific to a particular project and context. These criteria include environmental impact, efficiency, cost effectiveness, resources and their use, commercial availability and viability, and system integration options (e.g., dark fermentation coupled with anaerobic digestion) which need to be considered. Additional research is needed in a few key areas of research on the production of ammonia through waste utilization, environmental impacts of water usage for ammonia production and where an ammonia production plant needs to be located, in terms of both availability of feedstock and sustainability (accessibility to renewable energy sources such as solar Photovoltaic and wind power, distance from the waste hub to the production plant, etc.). In order to clearly address the problem associated with the reduction of water in ammonia production processes, meta-analysis of various technologies and stages for ammonia production is required. These factors need to be addressed in future studies. 


\section{AUTHOR CONTRIBUTIONS}

SG is the lead author and MV reviewed and edited the manuscript IW reviewed and edited the manuscript PS was the PhD Supervisor and reviewed and edited the manuscript.

\section{REFERENCES}

Acar, C., and Dincer, I. (2018). "3.1. Hydrogen production," in Comprehensive energy systems. Editor I. Dincer (Oshawa: Elsevier), 3-39.

Akroum-Amrouche, D., Abdi, N., Lounici, H., and Mameri, N. (2013). "Biohydrogen production by dark and photo-fermentation processes," in 2013 International Renewable and Sustainable Energy Conference (IRSEC), Ouarzazate, Morocco, March 7-9, 2013 (IEEE), 499-503.

Alcamo, J., Flörke, M., and Märker, M. (2007). Future long-term changes in global water resources driven by socio-economic and climatic changes. Hydrological Sci. J. 52 (2), 247-275. doi:10.1623/hysj.52.2.247

Ali, M., Zhou, F., Chen, K., Kotzur, C., Xiao, C., Bourgeois, L., et al. (2016). Nanostructured photoelectrochemical solar cell for nitrogen reduction using plasmon-enhanced black silicon. Nat. Commun. 7 (11335), 1-5. doi:10.1038/ ncomms 11335

Amar, I. A., Lan, R., Petit, C. T. G., and Tao, S. (2011). Solid-state electrochemical synthesis of ammonia: A review. J. Solid State Electrochem. 15 (9), 1845-1860. doi:10.1007/s10008-011-1376-x

Argun, H., and Kargi, F. (2010). Photo-fermentative hydrogen gas production from dark fermentation effluent of ground wheat solution: Effects of light source and light intensity. Int. J. Hydrogen Energ. 35 (4), 1595-1603. doi:10.1016/j. ijhydene.2009.12.040

Arora, P., Hoadley, A. F., Mahajani, S. M., and Ganesh, A. (2016). Small-scale ammonia production from biomass: a techno-enviroEconomic perspective. Ind. Eng. Chem. Res. 55, 6422-6434. doi:10.1016/j.jclepro.2017.01.148

Arora, P., Hoadley, A. F. A., Mahajani, S. M., and Ganesh, A. (2017). Multiobjective optimization of biomass based ammonia production - potential and perspective in different countries. J. Clean. Prod. 148, 363-374. doi:10.1016/j. jclepro.2017.01.148

Arora, P., Sharma, I., Hoadley, A., Mahajani, S., and Ganesh, A. (2018). Remote, small-scale, 'greener' routes of ammonia production. J. Clean. Prod. 199, 177-192. doi:10.1016/j.jclepro.2018.06.130

Arslan, C., Sattar, A., Changying, J., Nasir, A., Mari, I. A., and Bakht, M. Z. (2015). Impact of $\mathrm{pH}$ management interval on biohydrogen production from organic fraction of municipal solid wastes by mesophilic thermophilic anaerobic codigestion. Hindawi: BioMed Research International, 1-9.

Bicer, Y., and Dincer, I. (2018). Life cycle assessment of ammonia utilization in city transportation and power generation. J. Clean. Prod. 170, 1594-1601. doi:10. 1016/j.jclepro.2017.09.243

Bicer, Y., Dincer, I., Zamfirescu, C., Vezina, G., and Raso, F. (2016). Comparative life cycle assessment of various ammonia production methods. J. Clean. Prod. 135, 1379-1395. doi:10.1016/j.jclepro.2016.07.023

Bicer, Y. (2017). Investigation of novel ammonia production options using photoelectrochemical hydrogen. $\mathrm{PhD}$ thesis. Oshawa: University of Ontario Institute of Technology Faculty of Engineering and Applied Science.

Bolzonella, D., Battista, F., Cavinato, C., Gottardo, M., Micolucci, F., Lyberatos, G., et al. (2018). Recent developments in biohythane production from household food wastes: a review. Bioresour. Technol. 257, 311-319. doi:10.1016/j.biortech.2018.02.092

Brown, T. (2016). Ammonia as a renewable fuel for the maritime industry ammonia industry. Available at: https://www.ammoniaenergy.org/ammoniaas-a-renewable-fuel-for-the-maritime-industry/ (Accessed March 05, 2019).

Cavinato, C., and Pavan, P. (2011). Ottimizzazione del processo di digestione anaerobica a fasi separate dei rifiuti organici per la produzione di bio-hythane. Venezia: VALORGAS. Available at: https://docplayer.it/14982680Ottimizzazione-del-processo-di-digestione-anaerobica-a-fasi-separate-dei-rifiutiorganici-per-la-produzione-di-bio-hythane.html (Accessed June 05, 2020).

Chong, M.-L., Sabaratnam, V., Shirai, Y., and Hassan, M. A. (2009). Biohydrogen production from biomass and industrial wastes by dark fermentation. Int. J. Hydrogen Energ. 34, 3277-3287. doi:10.1016/j.ijhydene.2009.02.010

\section{FUNDING}

We wish to thank UKRI-BBSRC for funding to PS on grant BB/ M011917/1, Renewable Fertiliser Production to Improve Agricultural Efficiencies and Avoid Environmental Harm.

Chu, C. F., Li, Y. Y., Xu, K. Q., Ebie, Y., Inamori, Y., and Kong, H. N. (2008). A pHtemperature -phased two-stage process for hydrogen and methane production from food waste. Int. J. Hydrog. Energy. 33, 4739-4746.

CICE (2016). The essential chemical industry. Available at: http://essential chemicalindustry.org/chemicals/ammonia.html (Accessed June 05, 2020).

Ciranna, A. (2014). Biohydrogen production in extreme conditions: a comprehensive study of the fermentative metabolism of a polyextremophilic BacteriumPhD thesis. Tampere: Tampere University of Technology, 220.

Cong, L., Yu, Z., Liu, F., and Huang, W. (2019). Electrochemical synthesis of ammonia from $\mathrm{N} 2$ and $\mathrm{H} 2 \mathrm{O}$ using a typical non-noble metal carbon-based catalyst under ambient conditions. Catal. Sci. Technol. 9, 1208-1214. doi:10. 1039/c8cy02316f

De Gioannis, G., Muntoni, A., Polettini, A., and Pomi, R. (2013). A review of dark fermentative hydrogen production from biodegradable municipal waste fractions. Waste Manag. 33, 1345-1361. doi:10.1016/j.wasman.2013.02.019

Dincer, I., and Bicer, Y. (2018). "3.2 ammonia production," in Comprehensive energy systems. Editor I. Dincer (Oshawa: Elsevier), 42-82.

Distefano, T., and Kelly, S. (2017). Are we in deep water? Water scarcity and its limits to economic growth. Ecol. Econ. 142, 130-147. doi:10.1016/j.ecolecon. 2017.06.019

Elgowainy, A. (2015). Life-cycle analysis of water consumption for hydrogen production. Arlington: Annual merit review and peer evaluation report, 8-12.

Ercin, A. E., and Hoekstra, A. Y. (2014). Water footprint scenarios for 2050: a global analysis. Environ. Int. 64, 71-82. doi:10.1016/j.envint.2013.11.019

FAO (2009). How to feed the world in 2050? Rome, FAO. Available at: http://www. fao.org/fileadmin/tempelates/wsfs/docs/expert_paper/How_to_Feed_the_World_ in_2050.pdf (Accessed January 05, 2018).

Frattini, D., Cinti, G., Bidini, G., Desideri, U., Cioffi, R., and Jannelli, E. (2016). A system approach in energy evaluation of different renewable energies sources integration in ammonia production plants. Renew. Energ. 99, 472-482. doi:10. 1016/j.renene.2016.07.040

Ganley, J. C., Holbrook, J. H., and McKinley, D. E. (2015). Solid state ammonia synthesis. Available at: https://nh3fuelassociation.org/wp-content/uploads/ 2012/05/ssas_oct2007_final.pdf (Accessed January 05, 2018).

Garagounis, I., Kyriakou, V., Skodra, A., Vasileiou, E., and Stoukides, M. (2014). Electrochemical synthesis of ammonia in solid electrolyte cells. Front. Energ. Res. 2, 1-10. doi:10.3389/fenrg.2014.00001

Ghimire, A., Frunzo, L., Pirozzi, F., Trably, E., Escudie, R., Lens, P. N. L., et al. (2015). A review on dark fermentative biohydrogen production from organic biomass: process parameters and use of by-products. Appl. Energ. 144, 73-95. doi:10.1016/j.apenergy.2015.01.045

Giddey, S., Badwal, S. P. S., and Kulkarni, A. (2013). Review of electrochemical ammonia production technologies and materials. Int. J. Hydrogen Energ. 38 (34), 14576-14594. doi:10.1016/j.ijhydene.2013.09.054

Greenlee, L., Foster, S., Acharya, P., Suttmiller, D., Loney, C., Renner, J., et al. (2017). "Topical conference: NH3 Energy," in AIChE annual meeting, Minneapolis, October 29-November 3, 2017

Gross, M. D. (2008). H2 production by natural gas assisted steam electrolysis. CACHE modules on energy in the curriculum. Available at : http://webcache. googleusercontent.com/search?q=cache:J32Y5x0o0cQJ:pages.mtu.edu/ jmkeith/ fuel_cell_curriculum/separations/module3/ALL.

$\mathrm{doc}+\& \mathrm{~cd}=3 \& \mathrm{hl}=\mathrm{en} \& \mathrm{ct}=\mathrm{clnk} \& \mathrm{gl}=\mathrm{us}$ (Accessed June 13, 2018).

Guerra, C. F., Reyes-Bozo, L., Vyhmeister, E., Caparros, M. J., Salazar, J. L., and Clemente-Jul, C. (2020). Technical-economic analysis for a green ammonia production plant in Chile and its subsequent transport to Japan. Renew. Energ. 157, 404-414. doi:10.1016/j.renene.2020.05.041

Guo, X., Du, H., Qu, F., and Li, J. (2019). Recent progress in electrocatalytic nitrogen reduction. J. Mater. Chem. A. 7, 3531-3543. doi:10.1039/c8ta11201k

Hawkes, F., Hussy, I., Kyazze, G., Dinsdale, R., and Hawkes, D. (2007). Continuous dark fermentative hydrogen production by mesophilic microflora: principles 
and progress. Int. J. Hydrogen Energ. 32, 172-184. doi:10.1016/j.ijhydene.2006. 08.014

Heffer, P., and Prud'homme, M. (2016). Global nitrogen fertiliser demand and supply: trend, current level and outlook. Paris: IFA. Available at: https://www. fertilizer.org//images/Library_Downloads/2016\%20Global\%20nitrogen\% 20fertiliser\%20demand\%20and\%20supply.pdf (Accessed June 20, 2020).

Hoekstra, A. Y., Chapagain, A. K., Aldaya, M. M., and Mekonnen, M. M. (2011). The water footprint assessment manual setting the global standard. London, UK: Earthscan.

Hughes, T., Wilkinson, I., Tsang, E., McPherson, I., Sudmeier, T., Fellowes, J., et al. (2015). Green ammonia. Cardiff: SIEMENS. Available at: http:// businessdocbox.com/73271609-Green_Solutions/Green-ammonia-september2015.html (Accessed June 20, 2020).

IEA (2012). Energy technology perspectives 2012, pathways to a clean energy system. [Online] Available at: https://www.iea.org/publications/ freepublications/publication/ETP2012_free.pdf (Accessed May 01, 2020).

IEA (2007). Tracking industrial energy efficiency and CO2 emissions. Paris: OECD Publishing. Available at: https://www.iea.org/publications/freepublications/ publication/tracking_emissions.pdf (Accessed May 22, 2020).

IFA (2009). Energy efficiency and CO2 emissions in ammonia production. Available at: https: //www.fertilizer.org/images/Library_Downloads/2009_ IFA_energy_efficiency.pdf (Accessed June 09, 2018).

IPCC (2013). Climate change 2013: the physical science basis. Cambridge: Intergovernmental Panel on Climate Change. Available at: https://www.ipcc. ch/report/ar5/wg1/ (Accessed May 10, 2018).

Kapdan, I. K., and Kargi, F. (2006). Bio-hydrogen production from waste materials. Enzyme Microb. Technol. 38, 569-582. doi:10.1016/j.enzmictec. 2005.09.015

Kataoka, N., Ayame, S., Miya, A., Ueno, Y., Oshita, N., Tsukahara, K., et al. (2005). "Studies on hydrogen-methane fermentation process for treating garbage and waste paper," in ADSW 2005 Conference Proceedings. (Copenhagen, Denmark: . Process Engineering), 2.

Kevin Breen, K. B. (2012). Energy technology prospectives, pathways to a clean energy system. Paris: International Energy Agency. Available at: https://www. iea.org/publications/freepublications/publication/ETP2012_free.pdf (Accessed May 02, 2020).

Kordali, V., Kyriacou, G., and Lambrou, C. (2000). Electrochemical synthesis of ammonia at atmospheric pressure and low temperature in a solid polymer electrolyte cell. Chem. Commun. 17, 1673-1674. doi:10.1039/b004885m

Kothari, R., Kumar, V., Pathak, V. V., Ahmad, S., Aoyi, O., and Tyagi, V. V. (2017). A critical review on factors influencing fermentative hydrogen production. Front. Biosci. 22, 1195-1220. doi:10.2741/4542

Lan, R., Irvine, J. T., and Tao, S. (2013). Synthesis of ammonia directly from air and water at ambient temperature and pressure. Scientific Rep. 3 (1145), 1-7. doi:10. 1038/srep01145

Lapina, A., Holtappels, P., and Mogensen, M. B. (2013). Electrolytes and electrodes for electrochemical synthesis of ammonia. $\mathrm{PhD}$ thesis. Kongens Lyngby: Department of Energy Conversion and Storage, Technical University of Denmark.

Lee, Z.-K., Li, S.-L., Kuo, P.-C., Chen, I.-C, Tien, Y.-M., Huang, Y.-J., et al. (2010). Thermophilic bio-energy process study on hydrogen fermentation with vegetable kitchen waste. Int. J. Hydrog. Energy. 35(24), 13458-13466.

Liu, B.-F., Ren, N.-Q., Xing, D.-F., Ding, J., Zheng, G.-X., Guo, W.-Q., et al. (2009). Hydrogen production by immobilized R. faecalis RLD-53 using soluble metabolites from ethanol fermentation bacteria E. harbinense B49. Bioresour. Technol. 100, 2719-2723. doi:10.1016/j.biortech.2008.12.020

Liu, D., Angelidaki, I., Zeng, R. J., and Min, B. (2008). Bio-hydrogen production by dark fermentation from organic wastes and residues. $\mathrm{PhD}$ thesis. Kongens Lyngby: Department of Energy Conversion and Storage, Technical University of Denmark.

Liu, R., Xie, Y., Wang, J., Li, Z., and Wang, B. (2006). Synthesis of ammonia at atmospheric pressure with $\mathrm{Ce} 0.8 \mathrm{M} 0.2 \mathrm{O} 2-\delta(\mathrm{M}=\mathrm{La}, \mathrm{Y}, \mathrm{Gd}, \mathrm{Sm})$ and their proton conduction at intermediate temperature. Solid State Ionics 177, 73-76. doi:10.1016/j.ssi.2005.07.018

Loney, C., Graybill, A., Xu, C., Renner, J., Acharya, P., Suttmiller, D., et al. (2017). "NH3 Energy+Exploring peptide-bound catalysts for electrochemical ammonia generation," in AIChE annual meeting, topical conference, Minneapolis, October 29-November 3, 2017.
Luo, Y., Shi, Y., Li, W., Ni, M., and Cai, N. (2014). Elementary reaction modeling and experimental characterization of solid oxide fuel-assisted steam electrolysis cells. Int. J. Hydrogen Energ. 39, 10359-10373. doi:10.1016/j.ijhydene.2014. 05.018

Makhlouf, A., Serradj, T., and Cheniti, H. (2015). Life cycle impact assessment of ammonia production in Algeria: a comparison with previous studies. Environ. Impact Assess. Rev. 50, 35-41. doi:10.1016/j.eiar.2014.08.003

Marnellos, G., and Stoukides, M. (1998). Ammonia synthesis at atmospheric pressure. Science 282, 98-100. doi:10.1126/science.282.5386.98

Marnellos, G., Zisekas, S., and Stoukides, M. (2000). Synthesis of ammonia at atmospheric pressure with the use of solid state proton conductors. J. Catal. 193, 80-87. doi:10.1006/jcat.2000.2877

Marrony, M. (2015). Proton conducting ceramics: from fundamentals to applied research. Singapore: Pan Stanford Publishing Pte. Ltd.

Martinez-Frias, J., Pham, A. Q., and Aceves, M. (2003). A natural gas-assisted steam electrolyzer for high-efficiency production of hydrogen. Int. J. Hydrogen Energ. 28, 483-490. doi:10.1016/s0360-3199(02)00135-0

Matzen, M. J., Alhajji, M. H., and Demirel, Y. (2015). Technoeconomics and sustainability of renewable methanol and ammonia productions using wind powerd-based hydrogen. Adv. Chem. Eng. 5 (3), 1-12. doi:10.4172/2090-4568. 1000128

Mehmeti, A., Dimakis, A. A., Arampatzis, G., McPhail, S. J., and Ulgiati, S. (2018). Life cycle assessment and water footprint of hydrogen production methods: from conventional to emerging technologies. Environments 5, 1-19. doi:10. 3390/environments5020024

Michael, M., Alhajji, M., and Demirel, Y. (2015). Techn-oeconomics and sustainability of renewable methanol and ammonia productions using wind power-based hydrogen. Adv. Chem. Eng. 5 (3), 1-12. doi:10.4172/2090-4568. 1000128

Micolucci, F., Gottardo, M., Pavan, P., Cavinato, C., and Bolzonella, D. (2018). Pilot scale comparison of single and double-stage thermophilic anaerobic digestion of food waste. J. Clean. Prod. 171, 1376-1385. doi:10.1016/j.jclepro.2017.10.080

MIT News (2017). Explained: greenhouse gases. Available at: http://news.mit.edu/ 2017/explained-greenhouse-gases-0130 (Accessed June 09, 2018).

Morgan, E. R., Manwell, J. F., and McGowan, J. G. (2017). Sustainable ammonia production from U.S. Offshore wind farms: a techno-economic review. ACS Sustain. Chem. Eng. 5, 9554-9567. doi:10.1021/acssuschemeng.7b02070

Morgan, E. R. (2013). Techno-economic feasibility study of ammonia plants powered by offshore wind. $\mathrm{PhD}$ thesis. Amherst: University of Massachusetts Amherst.

Nordvang, E. (2017). Hydrogen production from ammonia for next generation carbon-free energy technologies. Denmark: AZO cleantech. Available at: URL: https://www.azocleantech.com/article.aspx?ArticleID=656 (Accessed January 05, 2020).

Parkinson, B., Tabatabaei, M., Upham, D. C., Ballinger, B., Greig, C., Smart, S., et al. (2018). Hydrogen production using methane: techno-economics of decarbonizing fuels and chemicals. Int. J. Hydrogen Energ. 43, 2540-2555. doi:10.1016/j.ijhydene.2017.12.081

Peng, P., Chen, P., Schiappacasse, C., Zhou, N., Anderson, E., Chen, D., et al. (2018). A review on the non-thermal plasma-assisted ammonia synthesis technologies. J. Clean. Prod. 177, 597-609. doi:10.1016/j.jclepro.2017.12.229

Pengyu, D., Lianhua, L., Feng, Z., Xiaoying, K., Yongming, S., and Yi, Z. (2017). Comparison of dry and wet milling pre-treatment methods for improving the anaerobic digestion performance of the Pennisetum hybrid. R. Soc. Chem. (Rsc) 7, 12610-12619. doi:10.1039/C6RA27822A

Peterson, B. (2017). Desalination and energy consumption energycentral. Available at: http://www.energycentral.com/c/ec/desalination-and-energy-consumption (Accessed August 17, 2018).

Pfromm, P. H. (2017). Towards sustainable agriculture: fossil-free ammonia. J. Renew. Sustain. Energ. 9, 1-20. doi:10.1063/1.4985090

Pham, A. Q., Wallman, H., and Glass, R. S. (2000). Natural gas assisted steam electrolyzer. U.S. Patent 6051125.

Philiber, C. (2018). Electro fuels: status and perspectives. Available at: https://www. iea.org/media/workshop/ElectrofuelsBackgrounddocument.pdf (Accessed June 13, 2020).

Reddy, K. (2016). Evaluation of biohydrogen production potential of sugarcane bagasse using activated sludge in a dark fermentation process. MSc thesis. Durban: Durban University of Technology (DUT). 
Roberts, T. L. (2009). The role of fertilizer in growing the world's food. Better crops with plant food in International plant nutrition institute (IPNI). Available at: http://www.ipni.net/publication/bettercrops.nsf/0/ D21DBC864569368D85257980006FC3DB/\$FILE/Better\%20Crops\%202009-2\% 20p12.pdf (Accessed January 15, 2020), Vol. 93, 12-15.

Sen, U., Shakdwipee, M., and Banerjee, R. (2008). Status of biohydrogen production. J. scientific Ind. Res. 67 (11), 980-993.

Service, R. F. (2018). Liquid sunshine. Science 361 (6398), 120-123. doi:10.1126/ science.361.6398.120

Singh, A., Sevda, S., Abu Reesh, I., Vanbroekhoven, K., Rathore, D., and Pant, D. (2015). Biohydrogen production from lignocellulosic biomass: technology and sustainability. Energies 8, 13062-13080. doi:10.3390/en81112357

Skodra, A., and Stoukides, M. (2009). Electrocatalytic synthesis of ammonia from steam and nitrogen at atmospheric pressure. Solid State Ionics 180 (23-25), 1332-1336. doi:10.1016/j.ssi.2009.08.001

Soloveichik, G. (2017a). "NH3 Energy Future of ammonia production: improvement of haber-bosch process or electrochemical synthesis?," in Topical conference: AIChE annual meeting, Minneapolis, October 29-November 3, 2017.

Soloveichik, G. (2017b). New generation of fuel cells: fast, furious and flexible. Washington, DC: ARPA-E. Available at: https://arpa-e.energy.gov/sites/ default/files/2017_Soloveichik_FastPitch_Final.pdf (Accessed June 05, 2020).

Szymanski, S., and Gellett, W. (2017). "Nitrogenase inspired peptidefunctionalized catalyst for efficient emission-free ammonia production," in 14th Annual NH3 Fuel Conference, AIChe Annual Meeting. Topical Conference: NH3 Energy, Minneapolis, November 1, 2017 (NH3 Fuel Association).

Tallaksen, J., and Reese, M.(2013). "Ammonia production using wind energy: an early calculation of life cycle carbon emissions and fossil energy consumption," in 10th Annual NH3 Fuel Conference Annual NH3 Fuel Conference. Sacramento, September 23, 2013 (NH3 Fuel Association).

Tapia-Venegas, E., Ramirez-Morales, J. E., Silva-Illanes, F., Toledo-Alarcón, J., Paillet, F., Escudie, R., et al. (2015). Biohydrogen production by dark fermentation: scaling-up and technologies integration for a sustainable system. Rev. Environ. Sci. Biotechnol. 14, 761-785. doi:10.1007/s11157-015-9383-5

Tenca, A. (2011). Biohydrogen production from agricultural and livestock residues within an integrated bioenergy concept. $\mathrm{PhD}$ thesis. Italy: Universita degli studi di Milano. Available at: https://air.unimi.it/retrieve/handle/2434/169992/ 169621/phd_unimi_R08109.pdf (Accessed January 05, 2018).

UN (2015). World population prospects: the 2015 Revision, key findings and advance tables. Working Paper No. ESA/P/WP.241. New York. Available at: https://esa.un.org/unpd/wpp/publications/files/key_findings_wpp_2015.pdf (Accessed February 25, 2020).

Valdez-Vazquez, I., and Poggi-Varaldo, H. M. (2009). Hydrogen production by fermentative consortia. Renew. Sustain. Energ. Rev. 13, 1000-1013. doi:10.1016/ j.rser.2008.03.003

Wang, L., Xia, M., Wang, H., Huang, K., Qian, C., and Maravelias, C. T. (2018). Greening ammonia toward the solar ammonia refinery. Joule 2 (6), 1-20. doi:10.1016/j.joule.2018.04.017
Wang, X., Yin, J., Xu, J., Wang, H., and Ma, G. (2011). Chemical stability, ionic conductivity of $\mathrm{BaCe} 0.9-\mathrm{xZrxSm0.10O3- \alpha and} \mathrm{its} \mathrm{application} \mathrm{to} \mathrm{ammonia}$ synthesis at atmospheric pressure. Chin. J. Chem. 29, 1114-1118. doi:10. 1002/cjoc.201190209

Wijers, F. K. (2011). Modeling a solid oxide fuel-assisted electrolysis cell in cycle tempo. MSc thesis. Delft: Delft University of Technology. Available at: https:// repository.tudelft.nl/islandora/object/uuid\%3A636d9620-8a57-4264-ad938b35a6168feb (Accessed June 8, 2020).

Will, M., and Lukas, L. (2018). Introducing renewable ammonia by Thyssenkrupp. Rotterdam, Netherlands: $\mathrm{NH}_{3}$ Event, 17-18.

Wilson, I. A. G., and Styring, P. (2017). Why synthetic fuels are necessary in future energy systems. Front. Energ. Res. 5, 1-10.doi:10.3389/fenrg.2017.00019

WVU (2016). Renewable energy to fuels through microwave-plasma catalytic synthesis of ammonia. Washington D.C.: ARPA-E. Available at: https://arpae.energy.gov/?q=slick-sheet-project/microwave-plasma-ammonia-synthesis (Accessed June 05, 2020).

Xu, G., Liu, R., and Wang, J. (2009). Electrochemical synthesis of ammonia using a cell with a Nafion membrane and $\mathrm{SmFe} 0.7 \mathrm{Cu} 0.3-\mathrm{x}$ Ni x O3 $(\mathrm{x}=0-0.3)$ cathode at atmospheric pressure and lower temperature. Sci. China Ser. B-Chem. 52, 1171-1175. doi:10.1007/s11426-009-0135-7

Yaswanth, L. (2018). Biohydrogen and volatile fatty acids production form food waste hydrolysate. MSc thesis. Halmstad: Halmstad University, Halmstad. Available at: http://www.diva-portal.org/smash/record.jsf?pid=diva2\% 3A1202202\&dswid=4852 (Accessed March 18, 2020).

Yoo, C. Y., Joo, J. H., Jang, S. Y., Yu, J. H., Jeong, H. N., Hyeong, C. H., et al. (2013). Electrochemical ammonia synthesis from water and nitrogen using solid state ion conductors. Sacramento: Ammonia energy association. Available at: https:// www.ammoniaenergy.org/paper/electrochemical-ammonia-synthesis-fromwater-and-nitrogen-using-solid-state-ion-conductors/ (Accessed June 8, 2020).

Zilouie, H., and Taherdanak, M. (2015). "Biohydrogen from lignocellulosic wastes," in Biofuel and biorefinery technologies. Editor K. Karimi (Switzerland: Springer), 253-288.

Schnitkey, G. (2016). Anhydrous ammonia, corn, and natural gas prices over time, farmdoc daily, department of agricultural and consumer economics, farmdoc daily (6):112 university of illinois of urbana-champaign. [Online]. Available at: https://farmdocdaily.illinois.edu/2016/06/anhydrous-ammonia-corn-and-naturalgas-prices.html (Accessed February 22, 2020).

Conflict of Interest: The authors declare that the research was conducted in the absence of any commercial or financial relationships that could be construed as a potential conflict of interest.

Copyright ( 2021 Ghavam, Vahdati, Wilson and Styring. This is an open-access article distributed under the terms of the Creative Commons Attribution License (CC $B Y)$. The use, distribution or reproduction in other forums is permitted, provided the original author(s) and the copyright owner(s) are credited and that the original publication in this journal is cited, in accordance with accepted academic practice. No use, distribution or reproduction is permitted which does not comply with these terms. 


\section{GLOSSARY}

AEM Anion Exchange Membrane

ATR Auto-thermal Reforming

CAPEX Capital Expenditure

COD Chemical Oxygen Demand

EPA Environmental Protection Agency

FAO Food and Agriculture Organization

GHG Green House Gas

GWP Global Warming Potential

HHV High Heating Value

HTE High Temperature Electrolysis

LCA Life Cycle Assessment

LHV Low Heating Value

MOO Multi Objective Optimization

NGASE Natural Gas Assisted Steam Electrolyzer

NTP Non-Thermal Plasma

OFMSW Organic Fraction of Municipal Solid Waste

OLR Organic Loading Rate
PEC Photo-electrochemical cells

SGP Specific Gas Production

SHP Specific Hydrogen Production

SMP Soluble Microbial Product

SMR Steam Methane Reforming

SOFEC Solid Oxide Fuel Electrolysis Cell

SOFC Solid Oxide Fuel Cell

SSAS Solid State Ammonia Synthesis

VFA Volatile Fatty Acid

MEC Microbial Electrolysis Cell

MFC Microbial Fuel Cell

NRR Nitrogen Reduction Reaction

UN United Nations

WVU West Virginia University

WVURC West Virginia University Research Corporation

$\mathrm{CO}_{2 \text { eq }}$ Carbon dioxide Equivalent

FE (\%) Faradic Efficiency (\%)

lux Illuminance

VS Volatile Solids 